\title{
Eş'arî Kelamının Selçuklu/Nizamiye ve Osmanlı Medreselerine Girişi ve Kimi Eş'arî Yorumların Toplumdaki Yansımaları
}

\author{
İbrahim COȘKUN \\ Prof. Dr., Necmettin Erbakan Üniversitesi, Ahmet Keleşoğlu İlahiyat Fakültesi, \\ Temel İslam Bilimleri Bölümü, Konya, Türkiye, ibrahimcoskun@ hotmail.com (Sorumlu Yazar/Corresponding Author)
}

\begin{tabular}{|c|c|}
\hline Makale Bilgileri & ÖZ \\
\hline $\begin{array}{l}\text { Makale Geçmişi } \\
\text { Geliş: } 28.09 .2020 \\
\text { Kabul: } 07.12 .2020 \\
\text { Yayın: } 25.12 .2020 \\
\text { Anahtar Kelimeler: } \\
\text { Sadeddin et-Teftazanî, } \\
\text { Şerhu'l-Akaid, } \\
\text { Osmanlı Medreseleri, } \\
\text { Eş’arîyye, } \\
\text { Türk dünyası. }\end{array}$ & $\begin{array}{l}\text { Eş'arîyye ve Mâtürîdîyye hicri üçüncü asrın sonlarında akaid ve kelam alanında teşekkül etmeye } \\
\text { başlayan Ehl-i sünnetin iki önemli ekolüdür. Bu iki ekol arasında bazı konularda görüş ayrılıklarının } \\
\text { olduğu açıktır. Bazılarına göre bunlar önemsiz lafzi ihtilaflar olarak kabul edilirken bazıları söz konusu } \\
\text { ihtilafları ciddi derin ihtilaflar olarak değerlendirmektedir. Bize göre de insan iradesi ve özgürlüğü } \\
\text { hüsün/güzel ve kubuh/çirkin, Allah'ın fiillerinde hikmet, sebep-sonuç ilişkisi vb. konularda Eş'arîyye ile } \\
\text { Mâtürîdîyye arasındaki görüş ayrılıkları ciddi ihtilaflardır. Çünkü konulardaki farklılıklar doğrudan } \\
\text { bireysel ve toplumsal hayata yansıyan konulardır. Eş'arîyye'nin bazı görüşleri belirgin bir şekilde } \\
\text { Selçuklular döneminde Nizâmiye Medreseleri aracıllı̆ı ile Türk dünyasında yayılmaya başlamış, sonraki } \\
\text { süreçlerde Sadeddin et-Teftazanî’nin "Şerhu'l-Akaid” adlı eseri başta olmak üzere pek çok Eş'arî kelam } \\
\text { âliminin eserlerinin Osmanlı Medreselerinde okutulmasıla Eş'arî din yorumu Türkler arasında hayli } \\
\text { etkili olmuştur. Osmanlı Devletinin duraklama ve gerileme dönemine bu etkilenme sonrasında girmiş } \\
\text { olması oldukça dikkat çekicidir. Biz makalemizde Mâtürîdîyye kelamının Türk-İslam dünyasındaki } \\
\text { serencamını, Nizamiye Medreselerinde sadece Şafii-Eş'arî âlimlerin görevlendirilme sebeplerini, Eş'arî } \\
\text { kelamının Osmanlı medreselerine girişini, etkilerini ve bu etkilenmenin bireysel ve sosyal hayattaki } \\
\text { yansımalarını değerlendireceğiz. }\end{array}$ \\
\hline
\end{tabular}

\section{The Entry of the Kalam of Ash'hari to Seljuk/Nizamiye and Ottoman Madrases and Reflections of Some Ash'ari Comments in the Society}

\begin{tabular}{|c|c|}
\hline Article Info & ABSTRACT \\
\hline $\begin{array}{l}\text { Article History } \\
\text { Received: } 28.09 .2020 \\
\text { Accepted: } 07.12 .2020 \\
\text { Published: } 25.12 .2020 \\
\text { Keywords: } \\
\text { Sadeddin Et-Teftazanî, } \\
\text { Şerhu'l-Akaid, } \\
\text { Ottoman Madrases, } \\
\text { As'hariyye, } \\
\text { Turkish World. }\end{array}$ & $\begin{array}{l}\text { Ash'arîyye and Mâtürîdyye are two important schools of Ahl as-Sunnah, which started to be formed in } \\
\text { the field of belief and kalam at the end of the Hijri 3th century. It is clear that there are differences of } \\
\text { opinion between these two schools on some issues. According to some, these are considered minor } \\
\text { verbal disputes, while others consider them serious deep disputes. In our opinion, the differences of } \\
\text { opinion between Ash'arîyye and Mâtürîdyye on matters such as human will and freedom, beauty and } \\
\text { ugly, mystery in Allah's actions, cause-effect relationship, etc. are serious conflicts. Because the } \\
\text { differences in the subjects are the issues directly reflected in individual and social life. Some of the views } \\
\text { of the Ash'arîyye were clearly spread in the Turkish world through the Nizâmiye Madrases during the } \\
\text { Seljuk period, and in the following processes, Sadeddin et-Teftazani's work named "Şerhu'l-Akaid" and } \\
\text { many Ash'arî theologians were taught in Ottoman Madrasas. The Ash'ari interpretation of religion has } \\
\text { been quite effective among the Turks. It is remarkable that the Ottoman Empire entered a period of } \\
\text { stagnation and decline after this influence. In our article, we will evaluate the history of the Mâturîdîyye } \\
\text { word in the Turkish-Islamic world, the reasons for the assignment of only Shafi-Ash'ari scholars in } \\
\text { Nizamiye Madrases, the entry of the Ash'ari theology into Ottoman madrasas, its effects and the } \\
\text { reflections of this influence on individual and social life. }\end{array}$ \\
\hline
\end{tabular}

Atıf/Citation: Coşkun, İbrahim. "Eş’arî Kelamının Selçuklu/Nizamiye ve Osmanlı Medreselerine Girişi ve Kimi Eş’arî Yorumların Toplumdaki Yansımaları”. Selçuklu Medeniyeti Araştırmaları Dergisi (SEMA) 5 (Aralık 2020), 1-24. https://doi.org/10.47702/sematr.2020.1 


\section{Gİiş}

Kelam ilmi İslâm dininin inanç esasları doğrultusunda hayata ve varlığa bakışı naslardan hareketle belirleyen ve aklî yöntemlerle temellendirip destekleyen bir ilimdir. Bu münasebetle temelini İslâm'ın iki kaynağı olan Kur'an-1 Kerîm ve Sünnete dayandırmış olmakla birlikte, tarihsel süreçte oluşmuş insanî tefekkürün izlerini taşımaktadır. Hicrî II. asırdan itibaren kendini hissettirmeye başlayan Kelâm ilmi, Vasıl b. Ata (ö.131/748) ve Amr b. Ubeyd'in (ö.144/761) öncülüğünde kısa zamanda önemli aşamalar kaydetmiştir. Sonraki asırda Ebu'l- Hüzeyl el-Allâf (ö.235/849), İbrahim en-Nazzâm (ö.231/845), Bişr b. El-Mu’temir (ö.210/825), Câhız (ö.255/869), Kâ’bî (ö.319/931) gibi önde gelen Mu'tezile düşünürleri Kelâm ilminin sistemleşmesinde, konularının ve yönteminin şekillenmesinde yer alan isimler olmuşlardır. ${ }^{1}$

Bu dönemde yabancı din, düşünce ve inanışların İslâm inancının içerisinde kendine yer bulma gayretleri, Şia ve Hâricîlik gibi çeşitli itikâdî fırkaların ortaya çıkmasına zemin hazırlamıştır. Bu fırkaların bir kısmı, köken itibarıyla siyasî anlaşmazlıkların üzerinde gelişmiş olsalar bile, zaman içerisinde akideleşme ve buna uygun bir düşünce atmosferi oluşturma sürecini gerçekleştirmişlerdir. Nitekim hicrî I. asrın sonlarından itibaren, Kitap ve Sünnet'e bağlılığı ile Müslümanların ana caddesini oluşturan kitle, Hasan-1 Basrî (ö.110/728), Ebû Hanife (ö.150/767), İdris eş-Şafiî (ö.204/820) gibi Ehli sünet-i hassa diye de ifade edilen selef âlimleri tarafından Şia, Hâricilik, Müşebbihe, Mücessime, Kaderiyye, Mürcie gibi, dönemin tartışılan firkalarıyla mücadele etmeye başlamışlardı. Sahih İslâm akidesinin ne olduğu, bizzat Kur'an ve Sünnet'e dayalı olarak ortaya konmaya, bunlardan uzaklaşanların yanlışlıkları gösterilmeye çalış1lıyordu. ${ }^{2}$ Ehl-i Sünnet-i amme diye de ifade edilen Mâtürîdîyye ve Eş'arîyye kelâmının, tam da bu süreç içerisinde, bunları takiben gelişen şartlar içerisinde ortaya çıktığını görmekteyiz.

Ebu'l-Hasen el-Eş'arî (ö.324/935-36), İslâm coğrafyasının merkezi olarak görülebilecek Basra'da kırk yaşında iken mensubu olduğu Mu'tezîle mezhebinden ayrılmış Ahmet b. Hanbel'in (ö.241/855) safina geçtiğini ilan etmiştir. Bir müddet sonra Ahmed b. Hanbel'in itikatta takip ettiği metodolojiyi yetersiz görmüş yazdığı esrelerle sonraki yıllarda kendi adıyla anılacak Eş'arîyye ekolünün temellerini atmıştır. ${ }^{3}$ Eş'arîlik, Kadı Ebubekir el-Bakıllanî (ö.403/1013) ve İbn Fûrek (ö.406/1015) tarafindan sistematik bir düşünce ekolüne dönüşmüştür. Selçuklular'ın kuruluş devrinde ise dönemin velûd ilim adamlarından İmâmü'l-Haremeyn Ebü'l-Meâlî el-Cüveynî (ö.478/1085), daha sonra da Ebu Muhammed el-Gazalî (ö.505/1111) ile gelişmesini sürdürdü. Abdülkerim eş-Şehristânî (ö.548/1153), Fahreddin er-Râzî (ö.606/1210) ve Seyfeddin el-Âmidî (ö.631/1233) ile bu din yorumuna felsefî boyut da eklendi. Adu'd-Din el-Îci (ö.755/1353), Seyid Şerif el-Cüranî 816/1413), Sadeddin et-Teftazanî (793/1390), Celaleddin ed-Devvanî (908/1502) gibi âlimlerle yoluna devam etti. Eş’arî düşünce adına dikkat çeken bir diğer boyut da Kuşeyrî (ö. 465/1072) ile başlayan el-Gazalî ile devam eden süreçte bu düşüncenin sûfîlik ile yakınlaşması oldu. ${ }^{4}$

Aynı coğrafyanın doğu sınırı olan Semerkand bölgesinde ise Ebu Mansur Muhammed b. Muhammed el-Mâtürîdî (ö.333/944), daha önce Ebu Hanife'nin temellerini attığı usul üzere Ehl-i sünnetin görüşlerini koruma ve yayma gayreti içerisindeydi. Bu ekol el-Mâtürîdî’nin öğerencisi Hakim

1 Ebu'l-Feth Muhammed b. Abdülkerim eş-Şehristanî, Kitabu'l-Milel ve'n-Nihal, thk. Muhammed Fehmi Muhammed (Beyrut: Daru'l-kütüib'l-ilmiyye, t.y.), 1/38.

2 Şehristânî, Kitabu'l-Milel ve'n-Nihal, 1/72-81.

${ }^{3}$ Şehristânî, Kitabu'l-Milel ve'n-Nihal, 1/72-81-84.

${ }^{4}$ Ebu'l-Abbas Şemsüddin Ahmed b. Muhammed İbn Hallikan, Vefeyâtu'l-Ayân ve Ebnâü Enbai'z-Zaman, thk. İhsan Abbas (Beyrut: Daru sadr, 1977), 3/205-208; Tacuddin Ebu Nasır Abdulvehhab b. Ali es-Subkî, etTabakâtu'ş-Şafiîyyetu'l-Kübra, nşr. Abdulfettah Muhammed el-Hulv-Mahmut Muhammed et-Tenâhî (Haleb: Daru Hicr,1964), 3/374; Abdülkerim Kuşeyrî, Kuşeyrî Risalesi, haz. Süleyman Uludağ (İstanbul: 1978), 12-13. 
es-Semerkandî (ö.343/953), Muhammed el-Pezdevî (ö.493/1100), Ebu'l-Mu'in en-Nesefî̀ (ö.508/1115), Ömer en-Nesefî̀ (ö.537/1142), Ali b. Osman el-Uşî (ö.575/1179), Nureddin es-Sabunî (ö.580/1184), Burhaneddin en-Nesefî (ö.687/1289), Ebu'l-Berekat en-Nesefî (ö.711/1310) ile yoluna devam etti. Osmanlı döneminde de İbn Hümam (ö.861/1457), Hızır Bey (ö.863/1458), Kemaleddin elBeyazî (ö.1098/1687), Kemal Paşazade (ö.940/1534) gibi pek çok kelam âlimi yetişti. ${ }^{5}$

Birbirlerinden habersiz, Müslüman dünyanın farklı iklimlerinde ortaya çıkan ve aynı temel değerlere dayanan bu iki hareket, bir süre sonra tek bir isim altında toplanmış ve o tarihten itibaren söz konusu bölgenin en etkili iki Kelâm ekolünü oluşturmuşlardır. Bu büyük tefekkür birikiminin itikâdî sahada temsiliyetini üstlenen Eş'arîlik ve Mâtürîdîlik ekolleri, zaman zaman birbirlerinden farklı açıklamalar ve yöntemlere dayanmaları sebebiyle görüş ayrılıklarına düşmüşlerdir. Bazen de kendi aralarında rekabet içerisinde olmuşlardır.

Bazılarına göre bunlar önemsiz lafzi ihtilaflar olarak kabul edilirken bazıları söz konusu ihtilafları ciddi derin ihtilaflar olarak değerlendirmektedir. Bize göre de Eş'arîyyenin Allah'ın ilim, irade ve kudret sıfatlarını sınırlar endişesiyle insan iradesini ve kudretini yok denecek tarzda yorumlar geliştirmesi, bunun sonucunda insanın sıradan pasif bir varlık konumuna düşürülmesi, hüsün/güzel ve kubuh/çirkin, hayır ve şerrin sadece vahiy ile bilinebileceği aklın bu konuda yetkili ve yeterli olmadığı, Allah'ın fiillerinde hikmetin aranamayacağı, sebeplerin müsebbebler/sonuçlar üzerinde hiçbir şekilde etkili olmadığı vb. konularda Eş'arîyye ile Mâtürîdîyye arasındaki görüş ayrılıkları ciddi ihtilaflardır. Çünkü bu konulardaki yaklaşımlar doğrudan bireysel ve toplumsal hayata etki eden konulardır. Zira yukarıda bahsettiğimiz kelâmî yorumlar, inanç olarak bir toplumun kültürel hayatına girdiğinde o toplumda yeterince tefekkür eden, araştıran, sorgulayan ve üreten kişiler yetişmez. Her çağda egemen olma ve yönetme arzusuyla toplumlar arasında çetin rekabetlerin ve savaşların yaşandığını dikkate aldığımızda böyle bir din yorumu ile hayatı yorumlayan toplumların güçlü bir konumda olmaları mümkün olmaz. ${ }^{6}$ Hâlbuki Allah, son ilahi dinin mensupları olan Müslümanların, iyiliği yayan kötülüklere karşı mücadele edebilen böylece diğer toplumlara örnek olacak bir pozisyonda olmalarını istemektedir. ${ }^{7} \mathrm{Bu}$ da bilim, kültür, sanat, iktisat, ticaret gibi önemli alanlarda güçlü olmayı gerektirir.

Tarih boyunca Müslüman Türklerin büyük çoğunluğu amelde Hanefî mezhebine itikatta ise Ehl-i sünnetin Mâtürîdîyye koluna mensup olmuşlardır. Fakat belli dönemlerde yaşanan sosyal ve siyasal olaylar veya kimi karizmatik liderlerin tercihleri sonucunda kısmı değişiklikler söz konusu olmuştur. Özellikle Eş’arîyye kelamı Büyük Selçuklu Devletinin gelişme döneminden sonra Türkİslam dünyasında hayli etkili olmuştur. Şimdi makalemizin hedefi olan Mâtürîdîyye kelamının Türkİslam dünyasındaki serencamını, Nizamiye Medreselerinde sadece Şafii-Eş'arî âlimlerin görevlendirilme sebeplerini, Eş'arî kelamının Osmanlı medreselerine girişini, etkilerini ve bu etkilenmenin bireysel ve sosyal hayattaki bazı yansımalarını irdeleyebiliriz.

\section{Hanefi-Mâtürîdiliğin Türk İslam Dünyasındaki Serencamı}

\section{Türklerin İslam'a Geçişi}

İslam dini miladî 7. yüzyılın ortalarından itibaren geniş bir coğrafyaya yayılmıştır. Türkler de bu dönemden itibaren İslam'a girmeye başlamışlardır. İslam tarihçileri Türklerin İslamlaşma sürecini Hz. Ömer (ö.23/644) döneminden Ömer b. Abdülaziz'in (ö.99/717) halife olmasına kadar olan süre ve Ömer b. Abdülaziz'in halife olması ve sonrasındaki süre olmak üzere iki ana bölümde

\footnotetext{
${ }^{5}$ Şerafettin Gölcük, Kelam Tarihi (İstanbul: Kitap Dünyası Yayınları, 2009), 53-69.

${ }^{6}$ Gazî et-Tevbe, Limaza Sagatat el-hilafetü'l-Osmaniyye (Beyrut: Mektebetu'l-İslamî, 2008/1429), 43-44.

${ }^{7}$ Bk. Âl-i İmran 3/110.
} 
değerlendirmektedirler. Bilindiği üzere Hz. Ömer döneminde 14/635 yılında gerçekleşen Kadisiye Savaşı ile Sasanî ordusu mağlup oldu. Bunun üzerine Arap orduları Horasan hattında fetihlere giriştiler. K1sa sürede Herat, Nişabur, Serahs gibi şehirleri ele geçirdiler. ${ }^{8}$ Böylece bu coğrafyada İslam dini duyulmaya başlamış oldu. Hz. Osman (ö.35/656) ve Hz. Ali (ö.40/661) dönemi karışıklıkları fetih projesinde yavaşlamalara neden olsa da Hz. Ali'nin şehit edilmesinden sonra kurulan Emevi Devleti, Hz. Muaviye (ö.60/680) döneminden itibaren oldukça planlı harekâtlar gerçekleştirmek suretiyle bölgenin fethini gerçekleştirdi. Bu dönemde Ziyad b. Ebîh'in genel komutasında Kuteybe b. Müslim, Horasan'da gerçekleşen Deyrülcemacim savaşında üstün başarılar kaydetti. Akabinde Rey valisi ardından da bölge genel valisi oldu. Oldukça dirayetli bir yönetim sergileyen Kuteybe b. Müslim (ö.96/715), Maveraünnehir bölgesine yönelik seferler de gerçekleştirmekteydi. Semerkant, Buhara gibi şehirler bu dönemde Emevî devleti sınırlarına dâhil oldu. Harezm ve çevresi ise barışçıl yollarla teslim alındı. Arap orduları Çin sınırına kadar ilerledi. Kuteybe, bir taraftan bölge hâkimiyetini sağlarken diğer yandan yaptırdığı camilerle ve uyguladığı politikalarla bölge halkının İslam'a girmesini sağladı. Bu dönemde bireysel olarak Türklerden Müslümanlığa geçenler oluyordu. ${ }^{9}$

Türklerin İslamlaşma sürecinde Ömer b. Abdülaziz döneminin ayrı bir yeri vardır. Bu dönemde diğer toplumlara karşı 1rkçı yaklaşımlardan vazgeçilmiş, Türkler ve diğer Arap olmayan unsurların İslam'a girmelerini hızlandıran politikalar çerçevesinde cizye ve haraç kaldırılmış, halkı küçük düşüren uygulamalara son verilmiştir. Bu uygulamalar bu bölgelerdeki insanların İslam'1 sevmesini sağlamıştır. ${ }^{10}$ Esasen Türklerin İslam'a kitleler halinde girmeleri Emevî Devleti'nin yıkılıp Abbasî Devleti'nin kurulması ile başlamıştır. Yeni kurulan devletin Horasan ve Maveraünnehir bölgesindeki uygulamaları büyük bir memnuniyetle karşılanmıştır. Abbasi Devletinin himayesinde kurulan ve 204-395/819-1005 yılları arasında hükümran olan Samanoğulları döneminde ise henüz İslam'a girmemiş Orta Asya içlerinde yaşayan Türklerin Müslüman olduğu bilinmektedir. Samanoğulları Buhara, Nişabur, Semerkant gibi şehirleri ilim merkezleri haline getirmişlerdir. İmam Mâtürîdî, İbn Sina (ö.428/1037), Ebu'l-Leys İbrahim es-Semerkandî (ö.373/983), Ebû Bekr Tâcülislâm el-Kelâbâzî (ö. 380/990) başta olmak üzere geniş yelpazede pek çok ilim adamı yetişmiştir. Samanoğulları'nın gazâ ve tebliğ niyeti taşıyan askeri hareketleri ile bölgede Cend, Yenikent gibi şehirler de inşa edilmiştir. ${ }^{11}$

225/840 yılında Talas'ta kurulan Karahanlı Devleti döneminde de yoğun bir şekilde Türklerin Müslümanlığa geçtiği bilinmektedir. Samanoğulları'nın yerini alan Karahanlılar, Müslüman olan Satuk Buğra Han'la birlikte bölgenin İslam dinine girmesine çaba göstermiştir. Kur'an-1 Kerim'in ilk defa Türk diline tercüme edilmesi bu dönemde gerçekleşmiştir. Boylar halinde binlerce Türk, Müslüman olmuştur. Karahanlılar döneminde İslam dinine giren Türkler, gazâ ve tebliğ faaliyetlerinde bulunmuş, özellikle iç bölgelerde İslam dininin kökleşip yerleşmesine büyük katkılar sağlamışlardır. ${ }^{12}$ Karahanlılar Devletinin yıkılmasından sonra kurulan Gazneliler Devleti döneminde de Müslümanlık

\footnotetext{
${ }^{8}$ Ebu Cafer Muhammed b. Cerir Taberî, Tarihu'l-umem ve'l-mülük, nşr. Ebu Suayb el-Keremî (Ürdün: t.y.), 583-587; Ebu'l-Fidâ İbn Kesîr, el-Bidâye ve'n-Nihâye, nşr. Hasan Abdülmennan (Beyrut: Beytü'l-Efkari'dDevliyye, 2004), 1/1045.

9 Taberî, Tarihu'l-Ümem ve'l-Mülük, 233-1255; İbn Kesîr, el-Bidâye ve'n-Nihaye, 2/1372-1385; Zekeriya Kitapçı, Orta Asya'da İslamiyet'in Yayllışl ve Türkler (Konya: Damla ofset,1994), 145; Mehmet Dalkılıç, "Buhara'nın İslamlaşmasında Kuteybe b. Müslim'in Rolü", Uluslararası Sosyal Araştırmalar Dergisi 5/23 (Güz 2012), 150.

${ }_{10}$ Taberî, Tarihu'l-Ümem ve'l-Mülük, 1283-1284; İmaduddin Halil, Melamihu'l-İnkilabi'l-İslami fi Hilafeti Ömer b. Abdülaziz (Beyrut: er-Risale, 1985), 81-176.

${ }^{11}$ Imadüddîn İsmail b. Ali b. Mahmud Ebu'l-Fidâ, Tarihû Ebi'l-Fidâ, thk. Mahmud Deyyûb (Beyrut:1997), 444448.

${ }^{12}$ Ali b. Salih el-Muheymid, "Karahanlılar ve İslam'ın Yayılmasına Katkıları”, çev. Ali Aksu, Cumhuriyet Üniversitesi Illahiyat Fakültesi Dergisi 5/1(2001), 281-309.
} 
Türkler arasında yayılmaya devam etmiştir. Özellikle Sultan Mahmud döneminde Hint alt kıtasında gazâ ve tebliğ faaliyetlerine ağırlık verilmiştir. ${ }^{13}$

Oğuzların Kınık boyundan olan Selçuklular, Maveraünnehir'e geldiklerinde küçük bir boy beyliği idiler. Fakat kısa sürede bölgesel sınırları aşan ilk Müslüman Türk devletini kurdular. Burada Müslüman oldular ve hizla devletleşme sürecine girdiler. Son derece rasyonel stratejileri ile hizla büyüyen ve güçlenen Selçuklular, Tuğrul Bey'in (ö.455/1063) önderliğinde Dandanakan'da (431/1040) Gazne devletinin varlığını ortadan kaldırarak Büyük Selçuklu Devletinin temellerini attılar. ${ }^{14}$ Tuğrul Bey, kurulan devletin ilk hükümdarı oldu ve 455/1063 yılına kadar hükümranlığını sürdürdü. Büyük Selçuklu Devleti'nin kuruluş devri olan bu dönemde Türklerin büyük çoğunluğu İslam dinine girmiş oldular. Fakat hâlihazırda Müslüman olmayan Türkler de bulunmaktaydı. Tuğrul Bey'in 1043 yılında Kaşgar ve Balasagun yöresine yönelmesiyle yaklaşık on bin çadır Türk nüfusunun Müslüman olduğu bilinmektedir. ${ }^{15}$ Sonraki yıllarda Türkler arasında İslamlaşma oranı hızla artmış Büyük Selçuklu Devletinden sonra kurulan diğer Türk devletlerinin kurucu kadroları ve halkların büyük çoğunluğu Müslüman Türklerden oluşmuştur.

Selçuklular ile Türkler parçacı hanedan yapısından sultanlığa geçişin, göçebe hayatından şehirciliğe uzanışın, pek çok açıdan zorlukları barındıran bir coğrafyaya hükmedişin hikâyesini barındırır. ${ }^{16}$ Başta Tuğrul Beyin hanedan üyeleri arasındaki çekişme ve isyanları bastırarak birlik ve beraberliği sağlaması merkezi yapıyı güçlendirmiştir. Bu başarıda Tuğrul Bey'in veziri Amîdülmülk Kündürî’nin (ö. 456/1064) payı da büyüktür. ${ }^{17}$ Onun döneminde Horasan bölgesindeki siyasi ve

${ }^{13}$ Montgomery Watt, İslam Düşüncesinin Teşekkül Devri, çev. Ethem Ruhi Fı̆̆lalı (Ankara: Umran Yayınları, 1981), 361; İbn Kesîr, el-Bidâye ve'n-Nihaye, 2/1794.

14 Ebu'l-Hasen İzzüddîn Ali b. Muhammed İbnü'l-Esîr, el-Kâmil fi't-Târih (Beyrut: Daru'l-kütübi'iilmiyye,1979), 9/478; İbn Kesîr, el-Bidâye ve'n-Nihaye, 2/1812; Muhammed b. Ali b. Süleyman Râvendî, Râhatü's-Südûr, çev. Ahmet Ateş (Ankara: 1957), 100.

${ }^{15}$ Osman Turan, Selçuklular Tarihi ve Türk İslam Medeniyeti (İstanbul: Boğaziçi Yayınları, 1996), 355.

${ }^{16}$ Abdullah Ömer Yavuz, "Büyük Selçuklu Devleti’nin Kuruluş Devrinde Mezhep Politikaları", Bilimname 34 (Ekim 2017), 512-513.

17 Ebu Nasr Amîdülmülk İmadüddîn Mansûr b. Muhammed el-Kündürî, Nişabur'un Turaysîs bölgesindeki Kündür köyünde 415/1024 yılında dünyaya geldi. Ailesi Şeybâniler'in Benî Cerrah koluna mensup olan elKündürî, küçük yaşlardan itibaren ilme meraklıydı. İlk eğitimin Nişabur'da aldı, Şair Ali b. Hasan Bâharzî ile birlikte ilim yolculukları yaptı, onunla Bâharzî arasındaki dostluk ömür boyu devam etti. Arapça, Farsça ve Türkçeyi oldukça iyi derecede bilen Kündürî, edebiyata da düşkündü. Ayrıca sanata ve fen ilimlerine de ilgilisi büyüktü. Kündürî, daha on altı yaşında devlet bürokrasisine adım attı. Tuğrul Bey genç yaşta onu yanına aldığı ve çeşitli görevler vererek yetişmesini sağladı. Merkez teşkilatındaki görevlerinde başarılı olması üzerine Harezm idaresinde görevlendirildi. Vezir Ribâtî’den sonra 445/1053 yılında Tuğrul Bey tarafindan vezirlik makamına getiridi. Kündürî’nin hayatının sonuna kadar sürdüreceği ve ölümüne neden olacak olayların yaşanacağı vezirlik dönemi, büyük bir önemi haizdi. Tuğrul Bey, vefatından önce Kündürî’nin de etkisiyle Çağrı Bey'in oğlu Süleyman’ı yerine vasiyet etti. Selçuklu bürokrasisinde çok etkili olan Kündürî, Tuğrul Bey'in defni sonrasında Süleyman'ı sultan ilan etti ve tahta çıkardı, adına hutbe okutulmasını emretti. Ancak aynı dönemde Alp Arslan'ın sultan olma arzusu ortaya çıkınca durum değişti. Bu durum karşısında Kündürî, hayli zor bir girdaba girdi. Bu dönemde Kutalmış da hükümdarlık iddiası ile Rey’e doğru hareket etti. Vezir Kündürî, Kutalmış tehlikesini iyi tahlil ederek devletin bekâsı için Alp Arslan'ın tahta oturması gerektiği kanaatine sahip oldu. Tahta çıkardığı halde etkisi hemen hiç hissedilmeyen Süleyman'ın Kutalmış karşısında tutunamayacağını gören Kündürî, Süleyman'ı tahtan indirdi ve Alp Arslan’ı sultan ilan edip adına hutbe okutmaya başladı. Alp Arslan, sultan olarak tahta çıktıktan sonra Vezir Kündürî'nin vezirlik görevine devam etmesini istedi. Fakat Sultan Alp Arslan'ın Kündürî ile yola devam etmesi kimi komutanlar ve yardımcısı Nizamulmülk tarafından hoşnutsuzlukla karşılandı. Ayrıca Alparslan’la Kündürî arasında güven bunalımına yol açan bazı olaylar da yaşandı. Söz konusu olaylardan bir süre sonra Vezir Kündürî görevden alındı ve yerine Nizamulmülk getirildi. Kündürî önce hapsedildi ardında da 456/1064 yılında idam edildi. (Ebu'l-Ferec Abdurrahman b. Ali İbnü'l-Cevzî, el-Muntazam fi Tarihi'l-Mülük ve'l-Ümem, thk. Muhammed Abdülkadir Ata (Beyrut: Daru'l-Kütüi'l-ilmiyye, 1995), 16/3; Aydın Taneri, "Büyük Selçuklu İmparatorluğunda Vezîrlik", Tarih Araştırmaları Dergisi 5/8 (1967), 87. 
dinî/mezhebî oluşumlar kontrol altına alınmıştır. Onun göreve gelmesi ile birlikte söz konusu coğrafyada birlik ve beraberlik sağlanabilmiştir. Bunun üzerine Selçuklular Bağdat'a yürümüşlerdir. O yörelerde boy gösteren isyanları bastırmışlardır. Daha kuruluş devrinde İslam dünyasının hâkimiyetini üstlenme niyetini ortaya koyan Selçuklular, Abbasî hilafetini Büveyhîlerin baskılarından kurtarırken bir taraftan Şî̂-İsmailî Fatımî Devletine, diğer taraftan Bizans'a karşı büyük mücadeleler vermiştir. ${ }^{18}$ Sonuçta oldukça karmaşık bir coğrafyada siyasî, ictimaî ve mezhebi karışıklıkların yoğun olduğu bir coğrafyada Büyük Selçuklu Devleti, varlığını korumuş ve uzun süre geniş bir coğrafyaya hükmetmiştir.

\section{İlk Müslüman Türk Devletlerinde Hanefilik ve Mâtürîtîlik}

Selçuklular'ın tarih sahnesine çıkmasının hemen öncesinde Horasan ve Maveraünnehir coğrafyası siyasî olarak çok kaotik görünüme sahip olduğu gibi mezhebî yapının da oldukça çeşitlilik arz ettiğini söylemiştik. Bununla birlikte Abbasi Devleti'nde Halife Ebu Ca'fer el-Mansur'dan (ö.158/775) sonraki üç Abbasi Halifesi döneminde Ebu Yusuf'un (ö.182/798) baş kadı olarak görev yapmasının bir sonucu olarak Ebu Hanife'nin öğrencilerinin bürokratik görevlere tayin edilmesi, Hanefî̀ düşüncenin bölge üzerinde ciddi bir etkiye sahip olmasını sağladı. Hanefî kadıların görevde kalmaları sebebiyle özellikle de İslam dünyasının doğu coğrafyasında Hanefîlik hızla yaygınlaştı. Abbasi iktidarında siyasal destekle kimi görevleri üstlenen Hanefîler, aynı zamanda Bağdat ve çevresinde de entelektüel birikimlerinin bir sonucu olarak hayli etkiliydiler. ${ }^{19}$

Karahanlılar'ın İslamlaştırma politikaları bir yandan Türklerin Müslüman olmasını sağlarken öte yandan Hanefî̀ düşüncesinin oldukça kapsamlı hale gelmesini ve güçlenmesini de sağlamıştır. Gazneliler döneminde ise önce Kerramiye mezhebinin sonra Şafii-Eş'arîliğin ön plana çıktığını görmekteyiz. Sultan Mahmud döneminde Hint alt kıtasında gazâ ve tebliğ faaliyetlerinin yoğun bir şekilde yapıldığı bir dönemde Kerramiyye mensupları, Sultan'ın güvenini kazanarak kendilerine alan açma gayreti göstermiş ve Eş'arîlerle mücadele etmek istemişlerdir. Ancak Sultan Mahmud bir süre sonra Kerramîlerden desteğini çekmiş ve Eş'arîleri desteklemiştir. Gaznelilerin bölgede gücünü arttırması ile Hint alt kıtasına ardı ardına seferler düzenleyen Sultan Mahmud, bir yandan da Batınî, Rafızî, Mu'tezilî kitleleri de Horasan'dan çıkarmanın gayretini taşımıştır. Halife Kadir Billah (ö.422/1031) tarafından yazıldığı iddia edilen “er-Risâletü'l-Kâdiriyye” çerçevesinde oluşturulan "Kadirî itikâdı" ${ }^{20}$ Gazneli Mahmud için Şafîi-Eş’arî düşüncenin bu bölgede desteklenmesine dayanak oluşturmuştur. Mu'tezile başta olmak üzere sözü edilen gayri Sünnî kimseler hapis, sürgün, idam gibi cezalara mahkûm edilmiş, minberden bu mezheplere lanet edilmiştir. ${ }^{21}$ Görüldüğü gibi Horasan ve Maverünnehir bölgelerinde Müslümanlar çeşitli itikâdî ve fikhî mezheplere ayrılmış vaziyetteydiler. Fakat Gaznelilerin haricinde Büyük Selçuklu Devleti öncesinde kurulan Türk Devletleri Hanefiliği ve henüz ismi konulmamış olsa da itikatta da Hanefi-Mâtürîdî düşünceyi benimsemişler ve desteklemişlerdir.

\footnotetext{
${ }^{18}$ İbnü'l-Esîr, el-Kâmil fi 't-Târih, 9/555; İbnü'l-Cevzî, el-Muntazam, 15/334; Râvendî, Râhatü's-Südûr, 106.

${ }^{19}$ Yavuz, Büyük Selçuklu Sultanı Tuğrul Bey Döneminde Mu'tezîle, 75.

20 Abbasi Devletinin gücünü kaybettiği bir dönemde halifelik görevini yapan Ebü'l-Abbâs el-Kâdir-Billâh Ahmed b. İshâk b. Ca'fer el-Abbâsî’nin Mu’tezilî düşüncenin tamamen yok edilmesi ve Sünnîliğin hâkim kılınması için özel çabalar sarf ettiği bilinmektedir. Bu konuda kaleme alınan er-Risâletü'l-Kâdiriyye (el-Usûl) adlı eser ona nispet edilmektedir. Bu eserde Ahmed b. Hanbel başta olmak üzere Ashab-1 hadisin düşünce ve yorumları doğrultusunda bir akide sistemi oluşturulmuş, Ashabın faziletlerinden bahsedilmiş, Ömer b. Abdülazîz'in üstünlükleri dile getirilmiş, Kur'an'ın mahlûk olduğuna inananların ve Mu'tezilî görüşü benimseyenlerin fikirlerinin yanlışlı̆̆ ispat edilmeye çalışılmıştır.

21 Abdullah Ömer Yavuz, Büyük Selçuklu Sultanı Tuğrul Bey Döneminde Mu’tezile (Kayseri: Erciyes Üniversitesi, Sosyal Bilimler Enstitüsü, Yüksek Lisans Tezi, 2015), 75-76.
} 


\section{Büyük Selçuklu Devleti Döneminde Hanefilik ve Mâtürîdîlik Tuğrul Bey Dönemi}

Büyük Selçuklu Devletinin kuruluş yıllarına tekabül eden Tuğrul Bey dönemi öncesinde Müslümanlar çeşitli itikâdî ve fikhî mezheplere ayrılmış vaziyette olsalar da Horasan ve Maveraünnehir coğrafyasında yaygın mezheplerin başında Hanefîlik gelmekteydi. Abbasiler'in Hanefîleri yargı başta olmak üzere pek çok göreve getirmeleri ve desteklemeleri neticesinde mevâlinin olduğu bölgelerde taban elde eden Hanefîlik, Tuğrul Bey dönemine gelindiğinde konumunu ve etkinliğini daha da güçlü hale getirmiştir. Selçuklular'ın Cend şehrinde Müslüman olmalarında da Hanefîliğin etkisi vardı. Cend'de İslam'a giren Selçuk Bey, dini öğrenmek için Samanoğulları'nın bölge valisine talepte bulunarak kendilerine dini anlatacak ilim adamları istemişti. Bu konuda İbn Kesîr (ö.748/1348) ise Tuğrul Bey'in Bağdat'a girişinden bahsederken onun Ehl-i Sünnete sevgi duyan ve koruyan birisi olduğunu söylemektedir. Sübkî (ö.756/1355) tarafindan da onun Hanefî̀ ve ilim sahibi bir insan olduğu vurgulanmaktadır. İbn Asâkîr (ö.600/1203) de Tuğrul Bey’i Hanefî olarak tanitmaktadir. ${ }^{22}$

Tuğrul Bey ve Selçuklu üst yönetiminin Hanefî olması, bu dönemde Hanefîlerin güçlenmesini sağlamıştır. Tuğrul Bey, Rey şehrini fethettiği zaman bir cami yaptırarak Hanefîlere vermiş ve Hanefîler bu camide bir araya gelmeye, toplantılar düzenlemeye başlamışlardır. ${ }^{23}$ Bürokratik atamalara bakıldığında Selçuklular'ın yaklaşımları daha da netleşmektedir. Aynı dönemde en dikkat çeken gelişmelerden biri de 447/1056 y1lında Hanefî Ebu Abdullah ed-Dâmegânî'nin (ö.478/1085) "Kâdılkudât"lık makamına getirilmiş olmasıdır. Hanefî Saîdî ailesinden gelen Ebu'l-Hasan İsmail b. Said (ö.443/1051) de dönemin önemli kadılarından birisidir. ${ }^{24}$ Bütün bunlar Hanefîliğin devlet kademesindeki yerini ve önemini göstermektedir. Sonuç itibariyle Tuğrul Bey döneminde Horasan merkezli Doğu Hanefîliğin geliştiği Selçuklu yönetiminin bu doktrinine esaslı katkılar sunulduğu anlaşılmaktadır. Bu dönemde Ebu Nasr el-İsbicâbî (ö.480/1087), Fahru'l-İslam Pezdevî (ö.482/1089), Şemsu'l-Eimme Serahsî (ö.483/1090) gibi Hanefî ilim adamları, Hanefîlik ve Mâtürîdîlik düşüncesini geliştirme gayreti göstermişlerdir.

Aynı dönemde Hanefílik, Bağdat'ın batısında da gelişme ve yayılma emareleri göstermiştir. Tuğrul Bey döneminde Hanefîler yargı başta olmak üzere birtakım görevlere getirilirken Şafiîler ise sahip oldukları görevlerden uzaklaştırılmışlardır. Dönemin önemli ilim merkezlerinden birisi olan Nişabur'da görev yapan Şafîi Ebu Osman es-Sabunî hatiplik görevinden alınmış, yerine Hanefî olan Ali b. Hasan es-Sandalî getirilmiştir. ${ }^{25}$ Selçuklu idaresinin Hanefîler'den yana tavır almasına karşıllık dönemin Abbasi halifesi ise Şafîi kimseleri göreve getirmekten çekinmemiştir. Şafîilerin, Selçuklu idaresi tarafından konumlandırılmasında Hanefîlerle aralarında yaşanan çatışmaların etkisinden bahsedilebilir. Bilindiği üzere Selçuklular bölgeye hâkim olmadan önce Hanefî̀ ve Şafiî kitleler arasında hayli ciddi çekişmeler ve çatışmalar yaşanmıştır. ${ }^{26}$

Selçukluların kuruluş devrinde itikâdî mezheplerin durumu ayrı bir öneme sahiptir. Siyasi itikâdî fırkaların fıkhî fırkalarla işbirliği ve ortaklıklar kurması bağlamında Tuğrul Bey dönemi çarpıcı gelişmelere tanıklık etmiştir. Selçuklular döneminde teşekkül sürecini sürdüren mezheplerin başında gelen Mâtürîdîlik, Samanoğulları döneminde Semerkant'ta yaşayan İmam Mâtürîdî’nin (333/944)

${ }^{22}$ Ebu'l-Kasım Ali b. Hasan b. Hibetullah İbn Asâkîr, Tebyînu Kezibi'l-Müfteri, nșr. M. Zahid el-Kevserî (Beyrut: Daru'l-kütüb'l-Arabî,1979), 108.

${ }^{23}$ Wilferd Madelung, "Mâtüridîliğin Yayılışı ve Türkler", çev. Muzaffer Tan, İmam Maturîdî ve Mâtürîdilik, haz. Sönmez Kutlu (Ankara: 2011), 330.

${ }^{24}$ Muyhiddin Ebu Muhammed Abdülkadir b. Muhammed Kureșî, el-Cevâhiru'l-Mudiyye fi Tabakâti'lHanefiyye, thk. Abdülfettah Muhammed el-Hulv (Beyrut: Daru hicr,1993), 412.

${ }^{25}$ İbn Asâkîr, Tebyînu Kezibi' 'l-Müfteri, 108.

${ }^{26}$ Ebu Abdillah Şihâbuddin Yakut el-Hamevî, Mu'cemu'l-Buldan (Beyrut: Daru Sadr, 1907), 1/202. 
görüşlerinin kurumsallaşması evresini yaşamaktadır. Bilindiği üzere Mâtürîdîlik, Hanefîliğin itikâdî görüşlerinin sistematik hale getirilmesi üzerine kuruludur. Bu sebepten dolayı Hanefîler, İmam Mâtürî̀î ve eserlerine büyük önem atfetmişler, Ehl-i Sünnet ve'l-Cemaatin önderlerinden kabul etmişlerdir. Fakat Mâtürîdîden hemen sonra onun düşüncelerini sistemleştirip geliştirecek miktarda güçlü âlimler yetişmemiştir. Mâtürîdîlik, Tuğrul Bey döneminde güçlü bir şekilde ilim adamlarının gündemine gelmiş ve İmam Mâtürîdî’nin görüşleri tartışılmaya başlanmıştır. Her ne kadar İmam Mâtürîdî ve eserleri tanınmaya başlasa da Selçuklular döneminde "Mâtürîdîyye" isimlendirmesine rastlanılmamaktadır. Tuğrul Bey döneminde Mâtürîdîlik adına söz edebileceğimiz tek isim Ebu'lYüsr Muhammed el-Pezdevî'dir. Kaynaklarda Mâtürîdî’nin görüşlerini ilk savunan isim olarak Pezdevî görülmektedir. Semerkant kadısı olan Pezdevî, Semerkant ve Buhara gibi Maveraünnehir şehirlerinde mesaisini harcamıştır. Her ne kadar Tuğrul Bey döneminde yaşamış olsa da Pezdevî'nin kadılığını yaptığı Semerkant, Sultan Melikşah döneminde Selçuklu topraklarına dâhil olmuştur. ${ }^{27}$

Tuğrul Bey döneminde mezhebî yapı açısından üzerinde durulması gerekenlerin başında Eş'arîlik gelmektedir. Zira bu ekol Mürcie'nin bir alt kolu olan Kerramiyyeye karşı mücadele etmesi için özel olarak Gazneli Mahmut tarafından desteklendiğini yukarıda ifade etmiştik. Tuğrul Bey döneminde Eş'arîler, Cüveynî ile güçlü bir konum elde etmişti. Bu dönemde dikkat çeken bir husus Kuşeyrî ile birlikte Eş'arîliğin Sûfî düşünceyle aynı fikir havuzunda buluşması oldu. Tuğrul Bey ve Selçuklular bölgeyi idare etmeye başladıklarında, pek çok mezhebin az ya da çok bir şekilde temsil edildiği bir sosyo-kültürel yapı ile karşılaşmışlardır. Burada dikkat çeken bir husus da mezheplerin birbirleriyle olan mücadeleleridir. Bu mücadele bugün Sünnî çatı içerisinde gördügümüz mezhepler arasında olduğu gibi diğer mezhepler arasında da meydana gelmiştir. Kargaşa ve çatışma ortamı Selçuklu dönemi öncesinden başlamış ve onların devrinde de devam etmiştir.

Selçuklular'ın kuruluş devri olan Tuğrul Bey döneminde Mâtürîdiliğin henüz gelişmesini sağlayamamış olması Mu’tezileye alan açmıştır. Bunun sonucunda bu dönemde Mu’tezile-Zeydiyye ilişkisi, Mu’tezile-İmamiyye ilişkisi ve Mu'tezile-Hanefîlik ilişkisiden bahsetmemize imkân sağlayan farklı mezheplerle ilişkili Mu’tezilî kimlikler söz konusu olmuştur. Tuğrul Bey döneminde öne çıan Mu'tezilî kimliğin, Mu’tezile-Hanefîlik ilişkisi şeklinde tezahür ettiğini söyleyebiliriz.

Ehl-i Rey-Ehl-i Hadis hakkında farklı tanımlamalar ve yorumlar olsa da bu meselede Hanefîler ve Mu'tezilîler sürekli olarak aynı kategoride yer almışlar ve Ehl-i Rey olarak isimlendirilmişlerdir. Ehl-i Rey, Ehl-i Hadis ayrışmasının nedenlerinden birisi de Arap-mevâli çekişmesidir. ${ }^{28}$ Çünkü Araplar, o dönemde ilmî faaliyetlerde, Mevalî ilim ehlinin çok gerisindedirler. $\mathrm{Bu}$ nedenle Ehl-i Hadis ilmi sadece rivâyet boyutuna indirmemiş ve Arap olmayan kitleyi rivâyet bilmemekle suçlamıştır. Arap-mevâli çatışmasının kökeninde, Emeviler'in asabiyet kökenli politikalarını da dikkate almak gerekir. Mu’tezile düşüncesinin genel itibariyle mevâli nüfusa dayanması, Ebu Hanife'nin de mevâli olması bir tür yakınlaşmayı beraberinde getirmiştir. Ayrıca aynı dönemde Emeviler'in Ali oğullarına yönelik baskı ve yok etme politikaları Zeyd b. Ali, Vâsıl b. Ata ve Ebu Hanife'nin yakınlaşmasını ortaya çıkarmışıır. ${ }^{29}$

Muhalefet bloğunda yer alan bu üç isim ilerleyen zamanda meydana gelecek gelişmelere de etki etmiştir. Nitekim Mu’tezilîler ve Zeydîler fıkıhta Hanefî mezhebini benimsemişlerdir. Dahası Mu'tezile ve Zeydiyye arasında, Mu’tezile ve Hanefîlik arasında Tuğrul Bey dönemi öncesinde ve onun devrinde yakınlaşmalar meydana gelmiştir. Tarihsel açıdan dikkat çeken bu gelişmelerin altında

\footnotetext{
${ }^{27}$ Kureşî, el-Cevâhiru'l-Mudiyye fi Tabakâti'l-Hanefiyye, 2/594.

28 İsmail Hakkı Ünal, İmam Ebu Hanife'nin Hadis Anlayışı ve Hanefî Mezhebinin Hadis Metodu (Ankara: Diyanet İşleri Başkanlığı Yayınları,1994), 44-47.

${ }^{29}$ Muharrem Akoğlu, “Büveyhîler'in Mezhebî Eğilimleri/Politikaları Üzerine”, Bilimname 17/1 (2009), 191.
} 
ilk dönemden itibaren aynı sosyolojik kökenden gelmeleri yer almaktadır. Mu'tezile-Hanefîlik ilişkisi Tuğrul Bey döneminin hemen öncesinde Büveyhîler döneminde yükselişe geçmiş, Ebu'l-Hasan Ubeydullah b. Hüseyin b. Dellâl el-Kerhî (ö.340/952), Cessas (ö.370/981), Ebu Abdillah Hüseyin elBasrî (ö.436/1044) gibi önemli ilim adamları yetişmiştir. ${ }^{30} \mathrm{Bu}$ dönemde Mu’tezile Hanefî yakınlaşması tüm Hanefîleri bu kategoriye dâhil olduğu anlamına gelmez. Nitekim bu dönemde Kerramiyye, Neccariyye hatta Eş'arîyyeden bazıları fikıhta Hanefî̀ idiler. Ayrıca bu dönemde Mâtürîdî mezhebi henüz oluşumunu tamamlamamış olsa da başta İmam Pezdevî olmak üzere Mu'tezile'ye eleştiriler yönelten bir kesim de bulunmaktaydı. Konumuz bağlamında düşünüldüğünde Tuğrul Bey döneminde Mu'tezilî kitlenin Hanefîlikle sağlam ilişkiler kurduğu ön plana çıkmaktadır. Mu'tezileHanefîlik ilişkisi yükselişine devam ederken Mu'tezile'nin Eş'arîlerle olan münakaşası da aynen devam etmiştir.

Tuğrul Bey dönemine kadar iki mezhep arasındaki çatışmalar üst perdeden devam etmiş, Tuğrul Bey dönemine gelindiğinde ise Mu'tezîlî olduğu iddia edilen Vezir Kündürî eliyle Eş'arîlerin aleyhine ciddi faaliyetlerinin olduğu bilinmektedir. Bu konuda Kündürî’nin ilk adımı, İmam Eş'arî ve Eş’arîliğe minberlerden lanet edilmesini gerçekleştirmiş olmasıdır. Önce Rafızîler için izin alınmış ardından İmam Eş'arî ve Eş'arîlik de bu izne dâhil edilmiştir. Lanetlemede "bid'at" kavramı öne çıkarılmış, İmam Eş'arî'nin bid'at ehli olduğu vurgulanmıştır. ${ }^{31}$ Daha önce de değindiğimiz üzere Tuğrul Bey döneminin hemen öncesinde Bakıllanî ve İbn Furek, Cüveyni gibi isimler çerçevesinde Eş'arîliğin kurumsallaşması söz konusudur. Esasen İmam Eş'arî'nin minberden lanetlenmesinin arka planında Eş'arîliğin güç kazanması vardır. Bu süreçin Tuğrul Bey döneminde artarak devam ettiği görülmektedir.

İmam Eş'arî'ye minberden lanet edilmesi ve Eş'arîliğin bid'atçilikle suçlanmasıyla birlikte Eş'arîlere yönelik baskı ve sorgulamalar başlamıştır. Selçukluların bu baskıları neticesinde Nişabur ve cıvarından yaklaşık dört yüz âlim ayrılmıştır. ${ }^{32}$ Gelişen hadiseler çerçevesinde Tuğrul Bey ve Vezir Kündürî'nin söz konusu uygulamaları sürdürmeleri üzerine başta Cüveynî, Beyhakî ve Kuşeyrî olmak üzere mağdur olmuş ilim adamları, söz konusu durum hakkında fetvalar yayınlamışlardır. Fetvalarda İmam Eş’arî’nin ilim ehli bir insan olduğu, lanetlenmesinin dinî hiçbir gerekçesinin bulunmadığı, dahası bu uygulamaların dinen caiz olmadığı anlatılmıştır. Şafîi, Eş'arî, Malikî ve kimi Hanefî ilim adamları bu konuda fetvalar vermişlerdir. ${ }^{33}$

Sürecin genel seyrine bakıldığında bazı uygulamaların toplumda infial uyandırdığı ve Eş'arî'ye lanet okunmasının haddinden fazla sert geçtiği anlaşılmaktadır. Yaşanan baskıların İslam coğrafyasında ciddi bir hoşnutsuzlukla karşılık bulması neticesinde Bağdat'ta ortamı yumuşatmak adına bazı adımlar atılmış olsa da bu dönem Selçuklu mihnesi olarak kayıtlara geçmiştir. Yaşanan olaylar, birlik ve beraberliği sağlama adına Alparslan ve veziri Nizamülmülk’ü itikatta Eş'arîliği, tasavvufta da Eş'arî düşünceden beslenen tasavvufi oluşumları desteklemeye teşekkül aşamasındaki Mâtürîdîliğin de ihmal edilmesine yol açtığını söyleyebiliriz.

\footnotetext{
${ }^{30}$ Muharrem Akoğlu, Büveyhîler Döneminde Mu’tezile (Ankara: İlahiyat Yayınları, 2008), 192-195; Yavuz, Büyük Selçuklu Sultanı Tuğrul Bey Döneminde Mu’tezile, 95-96.

31 İbnü'l-Esîr, el-Kâmil fi't-Târih, 10/32; İbn Kesîr, el-Bidâye ve'n-Nihaye, 2/1821; İbn Hallikan, Vefeyâtu'lAyân, 4/222; Sübkî, et-Tabakâtu'ş-Şafî̀yyetu'l-Kübra, 3/391; İbn Asâkîr, Tebyînu Kezibi'l-Müfteri, 108; Râvendî, Râhatü's-Südûr, 96-97; Bedevî, Mezâhibu'l-İslamiyyîn, 1/667; Ahmet Ocak, Selçuklular'ın Dini Siyaseti (İstanbul: Tatav Yayınlar1, 2002), 87-88.

32 İbnü'l-Esîr, el-Kâmil fi't-Târih, 10/33; Sübkî, et-Tabakâtu'ş-Şafî̀yyetu'l-Kübra, 3/393-394; İbn Asâkîr, Tebyînu Kezibi'l-Müfteri,108; Mehmed Şerefeddin Yaltkaya, "Selçukîler Devrinde Mezâhîb", haz. Seyit Bahcıvan, Marife 2/2 (Güz 2002), 267.

${ }^{33}$ Sübkî, et-Tabakâtu'ş-Şafî̀yyetu'l-Kübra, III/375; Yaltkaya, “Selçukîler Devrinde Mezâhîb”, 267-268.
} 


\section{Sultan Alparslan Dönemi}

Büyük Selçuklu Devleti’nin ilk sultanı Tuğrul Bey, 8 Ramazan 455/4 Eylül 1063 tarihinde Rey'deki sarayında vefat edince Sultan Alp Arslan başa geçmiştir. Yaşanan bazı hadiselerden sonra Sultan Alp Arslan, Kündürî’yi önce görevden almış, ardından kaleye hapsetmiş, 456/1064 yılında da idam ettirmiştir. Yerine ise asıl adı Hasan b. Ali b. İshak b. Abbas olan ve Hâce-i Buzurg lakabıyla bilinen Nizamülmülk’ü getirmiştir. ${ }^{34}$ Küçük yaşlardan itibaren ilme meraklı olan Nizamulmülk, dönemin önde gelen Eş’arî ve Şafîi ilim adamlarından dersler almıştır. Nizamulmülk'ün babası Gazneliler Devletinde görev almış, Selçuklular bölgeye gelince onların hizmetine girmiştir. Öncelikle Çağrı Bey'in yanına giden ve görev alan Nizamülmülk, Çağrı Bey tarafından oğlu Alparslan'a gönderilmiştir. Ailesi önemli siyasi görevler üstlendiği için Nizamülmülk, bölge siyasetini iyi bilen bir bürokrat olarak yetişmiştir. Tuğrul Bey vefat ettikten sonra Alparslan'ın sultan olması için mücadele eden Nizamülmülk, o sultan olduktan sonra Vezir Kündürî’nin görevden alınmasıyla vezirlik makamına gelmiştir. ${ }^{35}$ Devlet işlerindeki maharetiyle Sultan Alparslan ve oğlu Melikşah dönemlerinde görev yapan Nizamülmülk, Selçuklu siyaset ve mezhep yaklaşımına farklı bir yön vermiştir. Nizamülmülk'ün vezirliği döneminde Selçuklu mihnesinin tüm izleri silinmeye çalışılmıştır. Öncelikle Eş’arîleri lanetleme işine son verilmiştir. Kündürî döneminde Horasan'dan ayrılan Cüveynî, Kuşeyrî ve diğer Eş'arî, Şafîi, Sûfî ilim adamları Nizamülmülk'ün bizzat daveti ile Nişabur'a geri dönmüşlerdir. Selçuklular'ın dinî politikaları değişmiş, sürecin mağdurlarının gönülleri kazanılmak istenmiştir.

Nizamülmülk'ün İslam eğitim tarihinde önemli bir yeri vardır. $O$, resmi eğitim kurumlarıyla ilmin gelişmesi için gayret etmiş medreselere kitaplar bağışlamış araziler vakfetmiştir. Kendisi tarafından planlanan ve geliştirilen Nizamiye Medreseleri projesi ise Mihne sonrası uygulanan en önemli adımlardan biri olmuştur. Bu medreselerde Şii-Fatimîlerin Sünnî Abbasileri ve Selçukluları yıpratmak amacıyla siyasi ve askeri faaliyetlerin yanı sıra ilmi açıdan da yoğun bir propagandaya giriştikleri ve sakat öğretilerini yaymaya çalıştıkları dönemede Ehl-i sünnet akidesini güçlendirmek için ve devletin ihtiyaç duyduğu yerterli donanıma sahip görevlileri ve ilim adamlarını yetiştirmek için ülkenin her tarafına medreseler açmaya karar verdi. ${ }^{36}$ Yukarıda ismini zikrettiğimiz alimler ve İmam Gazalî gibi onların yetiştirdiği alimler İslam dinini yok etmeye çalışan Batinîlere karşı yazdıkları eserlerle ve fikri mücadelelerle önemli başarılar elde ettiler. ${ }^{37}$

İslam düşüncesinin geleceğine oldukça ciddi etkileri olan bu eğitim kurumları, aynı zamanda Şafiî-Eş'arî ve Eş'arî-Sûfî düşüncenin ciddi bir şekilde güç kazanmasına, Horasan ve civarında bu mezhebin hatırı sayılır bir taraftar edinmesine sebep olmuş, Selçuklu tarihindeki yerini almıştır. ${ }^{38} \mathrm{Bu}$ devasa eğitim kurumlarında Eş'arî-Şafîi dışında başka bir mezhebe mensup olanlara görev verilmemiştir. Nitekim Belh'de açılan Nizamiye Medresesinde görev yapacak Belhli Eş’arî-Şafîî müderris bulunamadığı için farklı şehirlerden getirilmek durumunda kalınmıştır. Bu medreselerin en büyüğü Bağdat'ta kurulmuştur. Bağdat Nizamiye Medresesinde 1091-1095 yılları arasında rektörlük ve müderrislik yapan Gazalî, kendi düşünce ve metodolojisinin haricindeki felsefi

\footnotetext{
${ }^{34}$ İbnü'l-Esîr, el-Kâmil fi't-Târih, 10/33.

${ }^{35}$ Yaltkaya, "Selçukîler Devrinde Mezâhîb", 268.

${ }^{36}$ Fethi Kerim Kazanç, “Bilge Vezir Nizamülmülk”, Gazzâlı̂’nin Feâhihu'l-Batiniyye Adlı Eseri Muvacehesinde Batinî Akımlarla Mücadele, ed. Musa Kazım Arıcan - Muhammed Enes Kala - Mehmet Tuğrul (Konya: Konya Büyükşehir Belediyesi Kültür Yayınları, 2019), 196-197.

${ }^{37}$ Bk. Ebu Muhammed b. Muhammed Gazzalî, Fedaihu'l-Batiniyye, thk. Abdurrahman Bedevî (Kahire: elMektebeu'l-Arabiyye,1963).

${ }^{38}$ Ahmet Ocak, "Medrese Geleneği İçinde Nizamiye Medreselerinin Önemi ve İlim Dünyasına Kazandırdığ Yenilikler”, Selçuklular'da Bilim ve Düşünce Sempozyumu (Konya: Türk Tarih Kurumu, 2013), 1/441-460.
} 
anlayışlara yer vermemiştir. ${ }^{39}$ Daha sonra bu medreselerin benzerleri İsfahan, Nişabur, Belh, Herat, Basra, Musul ve Amul'da inşa edilmiştir. Bu medreselerin ilk olarak Nişabur'da yaptırıldığına dair görüşler de vardır. Nizamulmülk'ün Nişabur'daki bu medreseyi Selçuklu Mihnesinde Hicaz’a gitmek zorunda olan Cüveynî için yaptırdığı aktarılmaktadır. Nitekim Cüveynî Nişabur'a geri döndüğünde bu medresede görev yapmıştır. ${ }^{40}$ Nişabur'un ilim merkezi olması hasebiyle önemi bir kat daha artan bu medrese, Eş'arî-Şafîi düşüncenin şekil aldığı yerlerden biri olmuştur. Cüveynî’nin dört yüz öğrencisinin derslere devam ettiği Nişabur Medresesinde Gazalî, Kuşeyrî’nin oğlu Abdürrahim el-Kuşeyrî (ö.405/1015) ve Muhammed b. Nasır el-Mervezî (ö.294/906) gibi ilim adamları görev yapmışlardır. ${ }^{41}$

Nizamiye Medreselerinin çok iyi planlanmış bir proje olduğu tarihsel süreçte ortaya çıkmıştır. Bir taraftan Eş'arî-Şafiî düşüncesi kurumlar vasıtasıyla geniş bir temsil imkânı bulmuş, diğer taraftan da yetişen öğrencilerle birlikte Eş'arî-Şafiî ve Eş'arî-Sûfî düşüncesi, Mu'tezilî, Hanefî-Mâtürîdî, Mâtürîdî-Sûfî ve Hanbelî düşüncelere karş1 güçlü bir konuma taşınmıştır. Bu dönemde Sultan Alparslan'ın Hanefîlik lehine bazı adımlar attığı söylense de Eş'arîlik karşısında Mâtürîdîliğin güçlendirilmesine yönelik özel bir politikasının olmadığı bilinmektedir.

Sultan Alparslan ve veziri Nizamülmülk'ün Nizamiye Medreselerinde Hanefiliğin ve Mâtürîdîliğin dışlanmasına ve bunun yerine amelde Şafii mezhebinin itikatta ise Ehl-i sünnetin Eş'arî ekolünün öne çıkarılmasına müsaade etmelerinin sebebi ile ilgili farklı yorumlar yapılmıştır. $\mathrm{Bu}$ yorumlardan öne çıkanı o dönemde İslam dünyasında Şii-batıni düşüncenin yaygınlık kazanma riskine karşı söz konusu yöneticilerin güçlü ve çok yönlü eserler vermiş olan Gazalî ve diğer Şafii-Eşarî âlimleri tercih etmiş olmalarıdır. Yine o dönemde Mâtürîdî ekole bağlı yeterli sayıda kapsamlı eserler vermiş olan kelam âlimlerinin olmaması iddiasıdır. ${ }^{42}$ Bizce Tuğrul Bey döneminde Şafîi-Eş'arî âlimlere yönelik uygulanan baskıcı politikaların etkisi daha büyük olmuştur. Sebep ne olursa olsun bu tercih Türk dünyasında Eş’arî din yorumunun yaygınlaşmasında dönüm noktası oluşturmuştur. Daha sonraki dönemlerde de bu firsat bir daha yakalanamamıştır.

Gazzâlî’ den itibaren Eş'arî kelamı Türkler de dâhil olmak üzere sünnî İslam dünyasında güçlü bir konum elde etmiş, Fahreddin Râzî' de zirveye ulaşmıştır. Râzî ile birlikte kelâm ilmi kuşatıcı ve yoğun bir inanç metafiziği hâline gelmiş, ardından Adudüddin el-İcî'den itibaren yaklaşık yüz yıllık bir dönemde muhtevalı ve sistematik şerhler başlamıştır. Bu dönemin belli başlı iki siması Sa'deddin et-Teftâzânî ile Seyyid Şerîf el-Cürcânî’dir. Îcî ile öğrencileri Teftâzânî ve Cürcânî gibi muhakkik kelâmcılar sayesinde daha derinlik kazanan kelâm düşüncesi, Anadolu Selçukluları ve Beylikler döneminde bu coğrafyada oluşan ilmî/tasavvufî zeminle kaynaşarak Osmanlı ilim dünyasına girmiştir. ${ }^{43}$ Şimdi bu süreci biraz daha detaylı inceleyebiliriz.

\section{Eş’arî Kelamının Osmanlı Medreselerine Girişi}

Genel görünümü itibariyle Osmanlı kelâm âlimleri, Eş’arî düşüncenin etkisi altında "müteahhirin" döneminin bir halkası ve tabii bir devamı konumunda olmuşlardır. Orhan Gazi döneminde İznik'te kurulan medrese Dâvud-i Kayserî'nin (ö.751/1350) öncülüğünde İslâm ilim mirasının Osmanlı'ya taşınmasının başlangıcı olmuştur. Osmanlı'nın kuruluş döneminde bütün İslamî

\footnotetext{
${ }^{39}$ Adülkerim Özaydın, "Nizâmiye Medresesi", Türkiye Diyanet Vakfi İslâm Ansiklopedisi (İstanbul: TDV Yayınlar1, 2007), 33/189-190

40 İbn Asâkîr, Tebyînu Kezibi'l-Müfteri, 108; Sübkî, et-Tabakâtu'ş-Şafî̀yyetu'l-Kübra, 3/392.

${ }^{41}$ İbn Hallikan, Vefeyâtu'l-Ayân, 3/167.

${ }^{42}$ Süleyman Uludağ, Kelam İlmi ve İslam Akaidi (İstanbul: Dergah Yayınları, 1980), 36; William Montgomery Watt, Íslam Felsefesi ve Kelam, çev. Süleyman Ateş (İstanbul: Pınar Yayınları, 2004),150.

${ }^{43}$ Said Özervarlı, Kelamda Yenilik Arayışları (İstanbul: İsam Yayınları, 2008), 24.
} 
ilimleri belli oranlarda toplayan âlimler ortaya çıkmıştır. Molla Fenârî (ö.835/1431) ilk örnek olarak zikredilebilir. O, hocası Cemaleddin Aksarayî'den (ö.791/1388) devşirdiği Fahreddin er-Râzî ekolü ile Ekmeleddin el-Bâbertî'den (ö.786/1384) tevarüs ettiği Hanefî-Mâtürîdî ekolünü ilmi kişiliğinde toplamış ve bunları tasavvuf düşüncesiyle yoğurarak yeniden inşa etmiştir. ${ }^{44}$

Fenârî ile birlikte Hızır Bey’i de (ö.862/1458) Osmanlı kelâmının kurucusu saymak gerekir. el-Kasîdetü'n-nûniyye'nin müellifi olan Hızır Bey, eser telifinden çok, kelâm dersleri vererek bu ilme hizmet etmiştir. Hayâlî (ö. 875/1470), Hocazâde (ö.893/1488) ve Kesteli'nin (ö.900/1495), hocaları olan Hızır Bey'den beraberce Seyyid Şerîf el-Cürcânî'nin Şerhu'l-Mevâkıf'ını okumuşlardır. İstanbul'a ilk kadı olarak tayin edilmesiyle birlikte Hızır Bey Fatih medreselerine taşınmıştır. Hızır Bey'in oğlu Sinan Paşa'nın (ö.891/1486) Molla Lutfi'yi (ö.1494), onun Kemalpaşazâde'yi (ö.941/1534), onun da Ebüssuûd'u (ö.984/1574) yetiştirdiği bilinmektedir. Burada dikkatimizi çeken husus Osmanlı kelamının kurucular konumunda olan âlimlerin bir Eş’arî kelamcısı olan el-Cürcânî’nin Şerhu'l-Mevâkıf'ını okumları ve okutmalarıdır. Şerhu 'l-Mevâkıf dışında Osmanlı kelâmına yön veren diğer eserler ise Teftâzânî'nin Şerhu'l- 'Akâid ve Şerhu'l-Makâsıd'l, İsfahânî'nin Şerhu't-Tevâli ve Şerhu't-Tecrîd'i ile Devvânî'nin Şerhu'l-Adudiyye'si sayılabilir. ${ }^{45}$

Görüldüğü üzere Nizamiye medreseleri ile başlayan Eş'arî kelam âlimlerinin etkileri Osmanlı medreselerinde de devam etmiştir. Osmanlı kelâmcıları Mâtürîdî oldukları bilinmesine rağmen onlar genel olarak Fahreddin er-Râzî çizgisindeki Eş'arî kelâm ekolüne mensup müteahhirin âlimlerin eserleri üzerinde yoğunlaşıp şerh ve haşiyeler yazmışlardır. Fazlur Rahman'a göre de Eş'arîlik yaklaşık bin yıllık bir tarih boyunca İslam dünyasının büyük bir kısmında mutlak hâkim olmuştur. ${ }^{46}$ Osmanlı teb'asının dinî zihniyetinin belirlenmesinde bir Eş'arî olan 'Huccetu'l-İslam' Gazzalî’nin halk için yazmış olduğu İhyâu Ulumi'd-Dîn, Kimyâ-i Saadet, Eyyuhelveled (Ey Oğul) gibi kitaplarının da Osmanlıca'ya çevrildiğini ve yaygın bir şekilde okunduğunu ve halâ okunmaya devam edildiğini belirtelim.

Osmanlı Medreselerinde Eş'arîliğin etkili olmasında Sadeddin et-Teftazanî ve onun "Şerhu'lAkaid" adlı eserinin ayrı bir yeri ve önemi vardır. Sa'düddin Mesud b. Ömer et-Teftazanî, Horasan'da Teftazan'da doğmuş, 797/1390 y1lında Serahs'ta vefat etmiştir. Meşhur kelâm âlimi Îcî onun hocasıdır. İbn Nüceym ve Ali el-Kârî gibi bazı âlimler O'nu Hanefî göstermişlerse de Teftazânî Şafiî ve Eş'arî geleneğe bağlı bir âlimdir. O İslami ilimlerin her alanında eserler vermiştir. Kelâm ilmine dair eserleri ise Şerhu'l-Akâidi'n-Nesefiye, Makâsıd ve şerhidir. ${ }^{47}$ Mehmed Ali Aynî'ye göre Teftazânî İslami ilimlerde yeni bir dönemi başlatan büyük bir İslam âlimidir. O, Timur ile birlikte Anadolu'ya gelmiş, pek çok âlimle tartışmalar yapmış ve her seferinde de başarılı olmuştur. ${ }^{48}$

Mehmet Ali Aynî'nin Teftezanî ile ilgili söylediklerinin tam aksini söyleyenler de mevcuttur. Onlara göre Teftazânî’ye kadar, bazen hızlı, bazen yavaş ilerleyen İslâm düşüncesi, ondan sonra dinamizmini ve yükselme kabiliyetini tamamen kaybetmiş durgun bir hale girmiştir. Çünkü Teftazânî'de yeni ve ileri düşünceler yoktu. Eskinin bir tekrarından ve özetinden ibaretti. el-Makâsıd ve Şerhu'l-Akâid'inde de bunu görmek mümkündür. Bununla birlikte Teftazânî'nin "Şerhu'l-Akâidi'nNesefiye" adlı eseri çağlar boyu geniş bir çevrenin alâkasına mazhar olmuştur. ${ }^{49}$ Başta Osmanlı medreseleri olmak Tüm İslam âleminde okunmuş ve okutulmuştur. Bu itibarla dünyadaki Sünnî Müslümanların büyük bir bölümünün inanç yapısında bu eserin önemli oranda etkisi olduğu şüphe

\footnotetext{
${ }^{44}$ Özervarl1, Kelamda Yenilik Arayışları, 25.

${ }^{45}$ Gölcük, Kelam Tarihi, 243-244.

${ }^{46}$ Fazlur Rahman, İslam ve Çă̆daşlık, çev. Alarslan Açıkgenç (Ankara: Ankara Okulu Yayınları, 1996), 270.

${ }^{47}$ Durmuş Özbek, Saduddin Teftazani ve Nüvvet görüşü (Konya: 2002), 43-44.

${ }^{48}$ Mehmet Ali Aynî, “Türk Mantıkçıları”, Daru'l-Fünûn İlahiyat Fakültesi Mecmuası 10/3 (1928), 52-53.

${ }^{49}$ Uludağ, Kelam İlmi ve İslam Akaidi, 62.
} 
götürmez bir gerçektir. Diğer ifade ile Şerhu'l-Akaid, medrese çevrelerine ve tüm Anadolu'daki hocalara fikir ve akîde yönünden şekil veren eser olmuştur. Medrese zihniyetinin teşekkülünde ve günümüze kadar devam etmesinde bu eserin payı büyük olmuştur. ${ }^{50}$

Metnu'l-Akâid'in müellifi Ömer Nesefî,, Mâtürîdî, Şârihi Teftazânî ise Eş'arî gelenektendir. Nesefi'nin akaid metni baştan sona kadar ne Mâtürîdî, ne de Eş'arî akâidine bağlı olarak şerh edilmiştir. Kestelî’ye göre Teftazânî, Ömer Nesefî’nin düşüncelerine bağlı kalarak söz konusu risaledeki konuların çoğunu Mâtürîdi geleneğe göre şerh etmiştir. Bekir Topaloğlu'na göre ise Şerhu'l-akâid, Eş'arîye mezhebine bağlı bir eserdir. Teftazanî, çoğu yerde doğrudan ve dolaylı bir şekilde Mâtürîdî görüşleri eleştirmiş ve Eş'arî yorumları öne çıkarmaya çalışmıştır. Topaloğlu görüşlerini şöyle sürdürür: "Bugün ilim mahfillerinde akâid ve kelâm sahasının en muteber kitabı vasfını devam ettiren Şerhu'l-akâid'in müellifi Teftazânî Eş'arîdir, hatta yer yer Mâtürîdî ulemasını ithamkâr tenkitlere maruz bırakıp Eş'arîyyeyi haklı çıkarmaya çalışmaktadır." ${ }^{51}$ Süleyman Uludağ da benzer kanaate sahiptir: "Şerh bütünüyle incelendiğinde prensip itibariyle Teftazânî'nin kafasına Eş'arî fikirlerin, kalbine de yine bu mezhebin inançlarının hâkim olduğu görülür. $O$, kelâmın esas ve önemli konularını işlerken bile bu meseleleri Eş'arîlere nisbet eder, Mâtürîdîlerin varlığından bile habersiz görünür." ${ }^{52}$ Şerhu'l-akâid'de canl1, hareketli, yeni, ileri bir kelâm anlayışı, değişen, gelişen ve çeşitlenmeler gösteren bir düşünce sistemi de mevcud değildir. ${ }^{53}$ Uludağ'a göre "Bu özellikteki bir kelâm ve akâid kitabı ile halkı medresede ve hocaların çevresinde toplamak ve tutmak elbette mümkün olmamıştır. Bunun içindir ki halk ve hatta okumuş ve aydınlar zümresi kendisine daha hisli, heyecanlı, hareketli, aynı zamanda hür düşünce ve serbest görüş beyan etmeye imkân veren tekkelere yığılmışlar ve şeyhlerin çevresinde toplanmışlardı. Kelâmın kuru ve katı tutumu tekkenin güçlenmesine sebep olmuştu. Medresede durgunlaşan fikir ve hisler tekkede hareketlenmiştir. Fakat medresenin ve kelâmcının yapması gereken şeyi tekkenin ve şeyhlerin yapması medrese için de tekke için de faydalı ve hayırlı sonuçlar doğurmamıştır.",54

Şerhu'l-akâid'de dikkat çeken bir husus da Teftazanî’nin Sünnî akâidini savunmak için Sünnî olmayan Mu'tezîle, Ca'feriye ve Zeydiye gibi İslâm mezhepleri gereğinden fazla eleştirmesidir. Ayrıca Teftezânî'nin artık neredeyse mensubu tükenmiş bir mezhep olan Mu'tezîle ile durmadan uğraşması o dönemde baş gösteren ve İslam âleminin geleceği açısından ciddi tehlikeler barındıran batınî karekterli oluşumların göz ardı edilmesine yol açmıştır. Yazdıkları haşiye ve ta'liklerle kendisini takib ve taklid edenler de İslâm dünyasını meşgul eden Batınî faaliyetleri, toplum içerisinde zaman zaman yaygınlık kazanan bâtıl inançları ve hurafeleri görememeleri ve bunlar hakkında bir tek söz bile söylememiş olmaları büyük bir eksikliktir. Teftazânî Şerhu'l-akâid'de âhâd hadislerin akâid konularında ölçü ve delil olmadığını ifade etmiştir. Buna rağmen dört-beş tanesi hariç eserinde delil olarak kullandığı tüm hadisler âhâddır. ${ }^{55}$

Mâtürîdîyye kelamının Türk-İ́slam dünyasındaki serencamını, Nizamiye Medreselerinde sadece Şafii-Eş'arî âlimlerin görevlendirilme sebeplerini, Eş'arî kelamının Osmanlı medreselerine girişini bu şekilde ifade ettikten sonra başta yöneticiler olmak üzere Müslüman Türklerin baştan itibaren ameli mezhep olarak Hanefiliği tercih ettiklerini ve bu mezhebin gelişerek devam etmesi için gayret gösterdiklerini söyleyebiliriz. Fakat itikadî mezhep olarak Mâtürîdîlik için aynı hassasiyetin gösterildiğini söyleyemiyoruz. Özellikle Alparslan'ın veziri Nizmülmülk ile birlikte Eş’arîliğin

\footnotetext{
${ }^{50}$ Uludağ, Kelam İlmi ve İslam Akaidi, 62.

${ }^{51}$ Bekir Topaloğlu, Mâtürîdîyye Akaidi (Ankara: Diyanet İşleri Başkanlığı Yayınları, 1979), 10.

${ }^{52}$ Uludağ, Kelam İlmi ve İslam Akaidi, 72.

${ }^{53}$ Bk. Saduddin et-Teftazanî, Haşiyetü Kestelli ala Şerhu'l-Akaid (İstanbul: Salah Bilici Kitabevi, 1966).

${ }^{54}$ Uludağ, Kelam İmi ve Íslam Akaidi, 82.

${ }^{55}$ Bk. Teftazanî, Haşiyetü Kestelli ala Şerhu'l-Akaid, 40.
} 
Nizamiye Medreselerinde oldukça etkili olduğunu, aynı düşünce geleneğinin Osmanlı Medreslerinde devam ettiğini yukarıda ifade etmiştik. Şimdi kimi Eş'arî yorumların bireysel ve sosyal hayatımızdaki etkilerini ve kâinata bakış tarzımızı nasıl etkilediğini irdeleyebiliriz.

\section{İhtilaflar ve Kimi Eş’arî Yorumların Toplumdaki Yansımaları}

Eş’arîlik ile Mâtürîdilik arasındaki ihtilafları inceleyen eserlere bakıldığında pek çok konudan bahsedilir. Görebildiğimiz kadarıyla ihtilafların özünde Eş'arîyyenin Allah tasavvuru ve bu tasavvura göre oluşturduğu kelam sistemi vardır. Allah inancı itikadî bir esastır. Fakat Allah inancı mutlaka bir tasavvura dönüşür. Bu tasavvurun oluşmasında psikolojik, sosyolojik, kültürel unsurlar büyük rol oynar. Şehristanî'nin ifade ettiği gibi Allah'a iman fitrîdir; ancak tasavvura dönüşürken onu tevhide göre oluşturmak her insan için en büyük sorumluluk konusudur. İnsanın en büyük imtihanı bu alanda gerçekleşir. ${ }^{56}$ Kişi fitratında var olan bu inancı batıl düşünce ve inançlardan korumakla yükümlüdür. Akıl, insanı Allah inancına götürürse de onu tevhid akidesine uygun bir tasavvura ulaştırması için vahiy bilgisine ihtiyaç duyar. Bunun içindir ki, Allah Teâla, peygamberler vasıtasıyla kendisini tanıtmıştır. Tarih boyunca ilahi bilgiyi dikkate almayanlar veya çeşitli sebeplerle vahiydeki temel mesajı kavrayamayanlar Allah tasavvuru konusunda aşırı tenzih veya aşarı teşbih gibi, iki aşırılıktan birine yönelmişler, teşbihte aşırıya kaçanlar putperestliğe, tenzihte aşırıya kaçanlar ise deizme ulaşmışlardır. ${ }^{57}$ Bunu Hıristiyan ve Yahudi teolojisinde açık bir şekilde görmekteyiz.

Hz Peygamberin vefatından bir müddet sonra da Müslümanlar arasında da bu konuda farklı görüşler ortaya çıkmıştır. Bunları üç gurupta toplayabiliriz. Birincisi: Allah’ı insana veya cisme benzeten Müşebbihe firkasıdır. İkincisi: Tenzihte aşırıya kaçan Mu'tezîle ve İslam Filozoflarıdır. Üçüncüsü: Tenzih ve teşbihteki aşırılıklardan uzak duran Ehl-i sünnete mensup Kelam Âlimleridir. Ehl-i Sünnet Kelam Âlimlerine göre Allah'ın insan ve kâinatla sürekli ilgili olduğunu kavrayabilmemiz için, kendini insan anlayışının alanına giren bazı sıfatlarla nitelendirmiştir. Fakat onlar Allah'ın yüceliğine uygun olmayan kavramları (tenzihi sıfatlar) onun zatından uzaklaştırmanın şart olduğunu da savunur. ${ }^{58}$ Böyle olmakla birlikte yukarıda ifade ettiğimiz gibi Ehl-i sünnetin Eş'arîyye ekolüne mensup mütekellimlerin büyük çoğunluğu yaşadıkları coğrafyaların, siyasal, sosyal ve kültürel ortamların neticesinde Allah'ın kudret sıfatını önceleyen bir metodolojiyi yeğlemişlerdir. $\mathrm{Bu}$ metodoloji sonucunda kullarına karşı güvensiz, bunun için de onları hür bırakmak istemeyen bir ulûhiyyet tasavvurunu öne çıkarmışlardır. Bu tasavvur sonucu ortaya çıkan pek çok problemden bahsedilebilir. ${ }^{59}$ Biz bu problemleri Eş’arîyyenin ve Mâtürîdîyyenin insana ve kâinata bakış açılarını karşılaştırarak değerlendireceğiz.

1) İnsana Bakış: Allah, insan türünün ilk örneği olan Hz. Âdem'i özel bir yaratışla farklı bir ihtimamla varlık alanına çıkarmıştır. Aslı toprak olan bu varlıkta Allah'ın "hay"(canlı olma, canlı kılma) ismi onda belirgin bir şekilde tezahür etmiştir. Allah ayrıca insana verdiği bilgi üretme yeteneği de (varlıkları isimlendirme) vererek varlıklar üzerinde tasarrufta bulunmasını murad etmiştir. ${ }^{60}$ İlk insanın eşiyle birlikte cennetten çıkarılış hikayesi bir yandan insanın zaaflarına işaret ederken diğer yandan "Sizi yeryüzünün halîfesi yapan, size verdiği imkânlar hususunda sizi denemek için kiminizi

56 Muhammed Abdulkerim eş-Şehristanî, Nihayetu'l-Ikdam fi- Ilmi'l-Kelam, thk. ve nşr. A. Guillauuame (Londra: 1934), 124.

${ }^{57}$ Bk. İbrahim Coşkun, “Teşbih ile Tenzih Arasında S. Âmidî’nin Allah'ın Sıfatlarını Yorumlamadaki Metodu”, Dicle Üniversitesi İlahiyat Fakültesi Dergisi 3/2 (2002), 27-28.

${ }^{58}$ Geniş bilgi için bk. Abdulkahir el-Bağdadî, el-Fark Beyne'l-Fırak (Beyrut: Daru'l-Marife,1997), 211-276; Mevlüt Özler, İslâm Düşüncesinde Tevhid (İstanbul: Nun Yayıncılık, 1995), 137-141.

59 Bk. Fethi Kerim Kazanç, "Eş’arî Kelam Sisteminde Allah Anlayışı ve Doğurduğu Sorunlar", Tanrı Tasavvurları ve Sosyal Hayata Yansımaları Sempozyumu, ed. Ramazan Biçer - Süleyman Akkuş (Sakarya: SÜ İlahiyat Fakültesi Yayınları, 2005), 107-142.

${ }^{60}$ Bk. Bakara 2/30-34. 
kiminizden üstün derecelerde kılan $O^{\prime} d u r . . . " 61$ ayetiyle onun yeryüzüne halifelik gibi bir seçkin misyonla gönderildiğine işaret etmektedir. Allah, insanı neden yeryüzünün halifesi yapmış olablilir?

Hilafet/niyabet, aslın yokluğu veya ona yardımcı olmak için gerekebilir. Bu insanlar için böyledir. Hiçbir şeye muhtaç olmayan Allah'ın bir varlı̆̆ 1 halife kılması bunlardan farklıdır. O bir şeref bahşederek yüceltmek istemesinden dolayı insanı kendine halife kılmıştır. ${ }^{62}$ Hilafet, esas itibariyle yeryüzünü imar ve sslah görevidir. Allah insanı bu görevin gerektirdiği yeteneklerle donatmıştır. Halife kelimesinin sözlük anlamından da anlaşılacağı gibi insan, arda gelen nesiller boyunca bu görevin yükümlülük ve sorumluluğu altındadır. Ashab-1 Kiram ve onları takip eden nesiller Hz. Peygamberin bildirdiği dini ve bu dinin inanç esaslarını en iyi şekilde kavradılar. Onlar Allah'tan Allah da onlardan razı oldu. ${ }^{63}$ Onlar Allah'a rağmen bir özne değil, Allah'ın, kendilerini yarattığını ve önemli bir misyonu yüklediğini ve bu misyonu yerine getirebilecek bir donanıma sahip olduklarına inandılar. Bu anlayışın bir sonucu olarak hayatın her alanda başarılı olmak için çaba sarfettiler. Yaşadıkları dönemin sosyal şartları çerçevesinde hayatın her alanında ne gerekiyorsa onu yaptılar. Kur'an ve sünneti doğru anladılar. Hz. Osman'ın şehadeti ve sonrasında yaşanan bazı talihsiz olaylar neticesinde kaza, kader, irade konularında ve ulûhiyyet telakkisinde kimi uç yorumlar ortaya çıkmışsa da bunlar İslam toplumunun genelini etkilemedi. Bunun neticesinde medeniyet tarihine önemli bir halka eklediler. Bu durum yaklaşık hicri beşinci asra kadar devam etti.

İslam Medeniyetinin gelişmesi hicri beşinci asra kadar devam etse de esasen üçüncü asrın başlarında ortaya çıkan siyasal olaylar ve sosyo-ekonomik ve kültürel şartlar neticesinde bu yapının değişmeye başladığını görmekteyiz. İlk olarak Müşebbihe firkası Allah'ı antropomorfik(insan biçimci) ve antropopatik(insan duygulu) bir varlık gibi tasavvur etmeye başladı. Kaderiye fırkası ise Müşebbihenin antropomorfik tanrı tasavvuruna karşı tenzih düşüncesini savunuyordu. Fakat kaderiye her türlü eksiklikten münezzeh kılma adına Allah'ı sıfatlarından soyutlanmış, hayali bir varlık konumuna getirdi. $\mathrm{Bu}$ düşünce biraz islah edilmiş haliyle Mutezilî âlimlerce geniş kesimlere ulaştırıldı. Onlar da tenzihte aşırılığa kaçarak Allah'ın sıfatlarını neredeyse yok saydılar. Muhatapları genelde felsefi ve akli delilleri kullandıkları için onlarda da akli delillere ağırlık verdiler. Fakat bu düşüncelerini içe dönüp Müslümanlara da yöneltince ciddi tartışmalar yaşandı.

Eş'ârîyye ve Mâtürîdîyye'den önce Ehl-i sünnetin yegâne temsilcisi olan ve sıfatıyye olarak da bilinen selefi âlimler, ayet ve hadislerle müşebbihe ve Mu'tezîlenin fikirlerini eleştirdiler. ${ }^{64}$ Fakat onların karşısında metotları yeterli olmadı. Kelamda haberi sıfatlar adıyla tartışılan ve teşbihi çağrıştıran nassları yorumlamayı uygun bulmadıkları için sonuç itibariyle müşebbiheye yakın bir konumda kaldılar. Naklin yanında aklı da mutlaka kullanmanın gereğini hisseden âlimler Mutezilenin düştüğü hatalara düşmeksizin Ehl-i sünnet kelamının teşekkülü için çaba sarfettiler. Bu çabaların sonucunda Eş'arîyye ve Mâtürîdîyye kelamı doğdu. Ebu'l-Hasen el-Eş'arî (ö.324/936), kırk yaşına kadar mutezîlî bir âlim iken hocası Ebû Ali el-Cübbaî (ö.303/916) ile fikir ayrılığına düştükten sonra Selefiyyenin yanında yer almış ve onların görüşlerini kelâmî yöntemlerle desteklemesiyle Sifatiyye ismi seleften Eş'arîliğe intikal etmişti. Artık Eş'arî, Ehl-i hadisin lideri konumunda olan Ahmed b. Hanbel'in safindaydı. Halife Mütevekkil'in mutezilî âlimlere karşı olumsuz bir tutum sergileyince Ashab-1 hadis güçlendi. Ebul Hasen el-Eş'arî bir müddet sonra Ashab-1 hadisin metodolojisinin yetersizliğini gördü ve kelami metotla güçlü bir konuma getirilmesi için çaba sarfetti. Fakat o çevrelerde bu yaklaşım fazla rağbet görmedi. Eş’ârîyye, Bakıllani, Ebû Bekr Muhammed b. El-Hasen

\footnotetext{
${ }^{61}$ En'am 6/165.

${ }^{62}$ Muhammed Hamdi Yazır, Hak Dini Kur'an Dili (İstanbul: Eser Kitabevi, 1971), 1/2199-300.

${ }^{63}$ Bk. Beyyine, 98/8

${ }^{64}$ Şehristânî, el-Milel ve'n-Nihal, 1/79-81; Sıddık Korkmaz, İmâm Mâtürîdî ve Mezhep Eleştirileri (İstanbul: İz Yayıncılık, 2017), $59 \mathrm{vd}$
} 
b. Fûrek el-İsfehânî (ö.406/1015) ve İmam Cüveynî gibi âlimlerle yoluna devam etti. Eş'arî kelamcılar haberi sıfatları tevil etme konusunda olduğu gibi bazı konularda zamanla Selefiyyenin görüşlerini yetersiz bularak daha rasyonel görüşler benimsemişlerse de Allah-insan ilişkisi bağlamında insanı, iradesi ve istitaatı olan bir fail olarak görmediler. İnsanda iradenin ve kudretin varlığını açıkça söyleyemediler. Bu düşünceler İslam dünyasında oldukça etkili oldu. Kur'an'da, açıkça bildirilmesine rağmen Allah'ın ilmi, iradesi ve kudreti yayında insanın bu yetenekleri neredeyse yok sayıldı. $\mathrm{Bu}$ anlayışlar insanın halifelik misyonunu gölgeledi.

$\mathrm{Bu}$ konular söz konusu olduğunda öncelikle cebriyye mezhebi akla gelir. Bu çağrışım doğrudur; ancak tarihte doğrudan insan hürriyetini yok sayanların sayısı oldukça az olmuştur. Fakat İslam Dünyasında Ehl-i sünnetin önemli bir ekolü olan Eş'arî kelamcıların benzer düşünceleri savunmuş olmaları oldukça dikkat çekicidir. Cebr-i mutavassıt (orta cebirci) olarak da isimlendirilen bu ekolün İslam dünyasında etkili olması ile Müslümanların İslam medeniyetinin parlak dönemindeki gösterdikleri performansı sürdüremedikleri bir döneme denk düşmesi oldukça dikkat çekicidir. İnsanın kudreti/istitâatı, iradesi ve bilgi üretme gibi insanı diğer varlıklardan farklı kılan özellikleri konusunda Mâtürîdîlerle Eş'arîlerin görüşlerini karşılaştırdığımızda bu durum daha iyi anlaşılacaktır.

a. Eş'arîyye ve Mâtürîdîyye'ye Göre İnsanın Kudreti/İstitâatı ve İradesi: Sözlükte kudret, insanın yapabileceği şeyler üzerinde dilediği etkiyi meydana getiren ve insana bir işi yapma veya yapmama sonucunu doğuran özellik olarak tanımlanır. Diğer ifade ile kudret, bir işi yapıp yapmama gücüne sâhip olmaktır. Mâtürîdîler de kudreti bu şekilde tarif etmektedirler. ${ }^{65}$ Eş’ârîlere göre kudret öyle bir güçtür ki, o güce sâhip olan her ne kadar dışarıdan bir emir sebebiyle bir işi işlemek ve ya işlememek zorunda olsa da, özü bakımından dilerse işlemeye, dilemezse işlememeye güç yetirir. ${ }^{66} \mathrm{Bu}$ tanıma dikkat edilirse kudret sâhibi olan, dilerse bir işi işler. Fakat bu durumda işlememek, o işten vaz geçmek elinden gelmez. Bunun gibi dilemezse işlemez. Fakat bu takdirde de işlemek, hattâ işlemeyi irâde etmek bile onun için mümkün olmaz.

Mâtürîdîlere göre kudret, "küllî”" ve “cüz'î” olmak üzere iki kısma ayrılır. Küllî olan, Allah'ın insan verdiği bütün ve potansiyel olan güç yetirme niteliğidir. Bu kudret, sebep ve vâsıtaların, bedendeki uzuv ve organların sağlam ve sağlıklı olmasıyla kendini gösterir. İnsan, bir fiili işleyip işlememe gücünü bununla elde eder. Cüz'î olan ise bir şeye yönlendirilmiş kudrettir. Diğer ifade ile cüz'î kudret bir bütün ve potansiyel hâlinde olan küllî kudretin belirli bir davranış ve iş için kullanılmasıdır. Fiil bununla meydana gelir. Fiil ile birlikte olur, fiilden önce veya sonra olmaz. Çünkü bu cüz'î kudret, küllî kudretin fiile çıkan kısmıdır. Küllî kudret ise fiilden önce de sonra da olur. Onun için cüz'î kudrete, "gerçek kudret" denir. ${ }^{67}$

Eş'arîler Allah'ın kudreti yayında başka bir fail ve güç kabul etmedikleri için insanın kudreti konusunda böyle bir ayrıma gitmezler. Kulun şahsında gerçekleşen fiilin o sırada Allah'ın verdiği kudretle gerçekleştiğine inanırlar. Bu kudret, fiilin karşılıklı olarak iki yönüne yeterli olmaz. Yâni bir fiilin işlenmesine ilişkin kudret başka, işlenmemesine ilişkin kudret başkadır. Yoksa aynı kudret bir fiilin hem işlenmesine, hem de işlenmemesine elverişli değildir. Mâtürîdîlere göre ise elverişlidir. Kudret konusundaki bu ayrımı ilk olarak Ebû Hanîfe yapmış ve şöyle demiştir: "İşlediklerinde mecbur olma fikri ile serbest olma fikri arasında orta yol; ancak gerçek kudretin, bir fiilin her iki

\footnotetext{
${ }^{65}$ Ebu Muhammed b. Muhammed el-Mâtürîdî, Kitabu 't-Tevhîd (Ankara: İsam Yayınları, 2003), 410-412.

${ }^{66}$ Ebu'l-Hasen el-Eş'arî, el-Luma, nşr. Richard Mc. Carthy (Beyrut:1952), 54,55,59; Kadı Ebu Bekr Muhammed el-Bakıllanî, Kitabu't-Temhid, nşr. R. MC. Carthy (Beyrut: 1957), 285.

${ }^{67}$ Mâtürîdî, Kitabu't-Tevhîd, 410 vd.
} 
yönüne elverişli olduğunu kabul etmekle bulunur. Kudretin bu yeterliliği kabul edilmezse, mecbur olma düşüncesinden kurtulmak mümkün olmaz." 68

İnsanın halife varlık olarak önemli bir özne olduğunun en temel göstergelerinden biri de sınırlı da olsa irade sahibi olmasıdır. İrâde, yapılabilecek iki şeyden birini diğerinden ayıran ve o şeyin meydana gelmesine sebep olan niteliktir. Mâtürîdîlere göre irâde de kudret gibi iki kısma ayrılır. Bunlara, "küllî irâde" ve "cüz'î irâde" denir. Küllî bütün ve potansiyel olan irâde, Allah'ın her insanın fitratına koyduğu bir yetenektir. Bu yetenek insanda fiile çıkmadıkça ve bir şeye fiilen ilgisi olmadıkça, ona "küllî irâde" adı verilir. Gerek bu küllî irâdenin ve gerek kudretin her iki türü, Cenâb-1 Hak tarafından yaratılmıştır. Bundan dolayı; kendi nefsimiz, vücûdumuz, her bir parçamız ve organlarımız nasıl yaratılmış ise, bunlar da öylece yaratılmıştır. Bunda görüş birliği vardır. Bu hususta Eş’ârîyye, Mâtürîdiyyehattâ, Mu'tezile arasında görüş ayrılığı yoktur. Cüz'î yani bir şeye yönlendirilmiş irâde ise kişinin küllî irâdesini, diğer ifadesiyle irâde gücünün, belirli bir işin iki veya daha fazla yönünden birine yoğunlaşması ve iradesini o yönde kullanmasıdır. İşte kasd, azim, niyet, ihtiyâr (seçebilme) kelimeleriyle dile getirilen mânâ ve kavram budur. ${ }^{69}$ İbn Hümâm, buna "azm-i musammem (kararlı niyet)" diyor. İşte cüz'î irâde demek, bu mânâyı ifâde etmektir. Mâtürîdî kelam âlimlerine göre "azm-i musammem/cüz'î irâde" insanın eseridir. Yaptıklarından sorumlu olması da bundandır. $^{70}$

Eş'arîler insan iradesi konusunda da küllî-cüz'î ayrımına gitmezler. Onlar Allah'ın iradesi yanında açıkça insan iradesinden bahsetmezler. Onlara göre irade, güçlü bir istek ve arzudan yani insanın bir işi işlemeyi veya işlememeyi tam olarak istemesinden ibarettir. Bu da başlangıçta birtakım etkenlerin gerektirdiği zorunlu bir niteliktir, istemeye bağlı değildir. İnsanın herhangi bir fiili işlemesi önce hoşa giden bir şeyi düşünmekle başlar. Sonra onu beğenir, niyet ve maksadına uygun olduğuna karar verir. İşte bu düşünce ve karar o fiili istemeyi gerektirir. Yani mecburen ve elinde olmaksızın bir istek meydana getirir. Bu istek, onu meydana getiren etkenlere bağlıdır, onlardan doğar. Onların zorlaması ile güçlenerek kast ve irade şeklini alır. Bunların hiçbirinde insanın payı yoktur ve kendi eseri değildir. Bunlar hep birbirine bağlı birer sebepler zincirinin sonucudur. Bu sebepler zincirinin hiçbir halkasında insanın kudretinin etkisi yoktur. Tam tersine insanın kudreti bunların ezici ve zorlayıcı etkisi altında tamamen yenik ve etkisiz bir haldedir. ${ }^{71}$

Eş’ârîlerin fikirleri aslında zorunluluk (determinizm) fikrini savunan filozoflarla aynıdır. Zira her iki fikirde, insanın kendi fiillerini, birtakım sebeplerin ve ilahi kudretin etkisi altında çaresiz bir halde, zorunlu ve mecburi olarak işlenmekten ibarettir. Böyle bir düşünce, insanın yükümlü olmasını anlamsızlaştırıyor. Çünkü insan işlediklerinde zorunlu ve mecbur olursa; onu bazı dini emir ve yasaklarla yükümlü tutmanın hiçbir anlamı kalmıyor. Bütün hareket ve davranışlarında kendi kudret ve iradesinin hiçbir hükmü ve etkisi olamayan, her ne yaparsa zorlayıcı ve ezici bir gücün etkisi altında yapmaya mecbur kalan insana şunu yap, bunu yapma demek; sonra yapmadığı, daha doğrusu yapamadığ 1 için onu sorumlu tutmak ve cezalandırmak saçma ve anlamsız olmaz mı?! Bu hal bir çocuğu zorla tutup baştan aşağıya suya batırdıktan sonra ben sana üzerini ıslatma demedim mi, niçin ıslattın diye cezalandırmaya benzer ki; izzet ve adalet, ilim ve hikmet sahibi olan Allah Teala'nın yüce

\footnotetext{
${ }^{68}$ Ebu Hanife, “el-Fıkhu'l-Ebsad”, haz. Mustafa Öz, İmam-ı Azamın Beş Eseri (İstanbul: İFAV Yayınlar,1992), 58; Muhammed İhsan Oğuz, İslam'da Kaza ve Kader (İstanbul: Oğuz Yayınları, 1993), 30-32.

${ }^{69}$ Mâtürîdî, Kitabu't-Tevhîd, 458 vd.

${ }^{70}$ Kemaleddin İbn Hümam, el-Müsayere (İstanbul: 1979), 60.

71 Eş'arî, el-Luma, 24; Saduddin et-Teftazanî, Şerhu'l-Makasıd (Beyrut, 1989), 2/347 vd.; Celaleddin edDevvânî, Celâl Şerhu'l-Akâidi'l-Adudîyye (İstanbul: Matbaa-1 el-Hac Muharrem Efendi el-Bosnevî, 1290), 3334.
} 
şanına bu ve benzeri şeyler nasıl yakışır? Hak Teala, bu gibi zulüm ve saçmalıklardan uzak ve yücedir. ${ }^{72}$

Eş'ârîler bu eleştirilere Cenab-1 Hak bütün varlıkları yaratandır, mülkünün tek sahibidir. Mülkünde dilediği gibi tasarruf eder. İradesine ve kudretine sınır koyacak veya karşı gelecek başka bir varlık yoktur. İşlediklerinden kimseye karşı sorumlu değildir. O’nun işlediğinin, zulüm ve saçmalıkla ilgisi olmaz diye cevap vermişlerdir.

b. Eş'arîyye ve Mâtürîdiyye'nin Kader Anlayışları: Yukarıda bahsettiğimiz Mâtürîdiyye ve Eş’arîyyenin kudret, irade, kesb ve insanın fiillerinin meydana gelişi ile ilgili düşünceleri aynı zamanda kaza ve kader inançlarına yansımıştır. Kader ve Kazaya iman, Allah'ın ilim, irade, kudret ve tekvin sıfatlarına iman etmenin bir gereğidir. Fakat Allah'ın teşriî iradesinin gereği olarak insan ve cinler gibi ilim, irade ve kudret yetenekleriyle yarattığı varlıkların iradi fiillerinde gerçekleşen kaderi ile tekvini iradesinin gereği olarak kâinatta işleyen ve asla değişmeyen kader farklıdır.

Bir insan, salgın hastalığın yaygın olduğu bir ortama korunaksız olarak girerse hasta olur. Fakat aynı insan, böyle bir ortama girmez ya da gerekli tedbirleri alarak girerse hasta olmaz. İşte birbirinin tam tersi olan bu iki sonucun ikisi de kaderdir. Cenab-1 Hak, ezelde sağlı ve hastalığın çeşitli sebeplerini takdir edip belirlerken; sözü geçen şu iki halden birincisini hastalık, ikincisini sağlık sebeplerinden olmak üzere takdir etmiş ve belirlemiştir. Biri hastalığın, diğeri sağlığın sebebi olan bu iki hal ve durum, kaderin sebeplerindendir. Takdir edilmiş ilahi birer kanun ve töredir. Sonuçları henüz meydana gelmeden önce Allah'ın ezeli ilminde vardır; Lehv-i Mahfuzda yazılıdır. Yani, ilmi bir varlık olarak Allah'ın ezeli ilminde vardır ve belirlidir. Şu halde bir kimse, kendi iradesiyle bu iki sebepten hangisine yapışırsa, onun sonucuyla karşılaşır. İşte bu kazadır. Aynı zamanda takdirin gereği olduğu için de kaderdir. ${ }^{73}$

Kaderin ikinci türü yani irade ve kudretimiz dışında gelişen talih olarak da ifade edilen kader, kaçınılmaz ve değişmez mukadderattır. İşte ilahi sır olan kader budur. Bu sırrı bilmek, bizim için mümkün olmaz. Bizim irade ve kudretimiz dışında geliştiği için bu kaderden, biz sorumlu tutulmayız. Bundan dolayı ne övülür ne de kınanırız. Yer ve gök felaketleri, onlardan meydana gelen hasarlar; bazılarımızın cılız, zayıf ve doğuştan hastalıklı olmamız, bazılarımızın güzel ve çirkin olması, bazılarımızın uzun veya kısa yaratılması bu tür kaderin örnekleridir. Fiziki âlemde geçerli olan kader de böyledir. Allah her şey için; ezelde onları meydana getiren bütün sebep ve şartları takdir edip, belirlemiştir. O yüzden, olan bütün olaylar, bu ilahi kanuna, töreye göre meydana gelmektedir. Allah "Sen, Allah'ın sünnet ve adetinde bir değişme bulamazsın" "74 buyurarak da bu kanunlarda bir değişme olamayacağını bizlere bildirmiş̧ir. İşte bundan dolayı kâinatta her ne zaman bir olay gerçekleşirse, mutlaka onun bir sebebi, bu sebebinde doğurduğu bir sonuç vardır.

Mâtürîdîler yukarıda örnekle açılamaya çalıştığımız bir kader anlayışına sahip iken Eş'arîyye böyle bir ayrıma gitmez. Fizikî âlemde işleyen kaderi anlatan pek çok ayeti de kendilerine delil olarak sunarlar. Onların delil olarak gösterdikleri ayetlerden biri olan "Yeryüzünde veya kendinizle ilgili bir musibet meydana gelmeden önce mutlaka bir kitaptadır",75 mealindeki ayeti İmam Mâtürîdî tefsir ederken önemli açıklamalarda bulunuyor. Ayette geçen 'önce' zarfı ile ilgili olarak 'insanlar yaratılmadan önce mi, yoksa musibet meydana gelmeden önce mi' diye sormakta ve şöyle demektedir: "Eğer insanlar yaratılmadan önce bir kitapta yazılıdır denirse, bu insan için her şeyin belirlenmiş olduğu anlamına gelir ki, insanın iradesi, özgürlüğü ve sorumluluğu devreden çıkmış olur. İnsan

\footnotetext{
${ }_{72}$ Oğuz, Íslam 'da Kaza ve Kader, 45.

${ }^{73}$ Mâtürîdî, Kitabu't-Tevhîd, 486-487.

${ }^{74}$ Fetih 48/23.

${ }^{75}$ Ahzab 33/72.
} 
yaşarken o musibet meydana gelmeden önce bir kitapta olması demek ise, o olayın bir kanuna göre meydana gelmesi demektir." "76 İmam Mâtürîdî, insanın seçimine tabi olan fiillerin "ilm-i ilâhî"de biliniyor olduğunu kabul eder. Ancak bu bilginin vasfedici bir ilgi olduğunu, diğer bir ifade ile insanın iradi fiillerinde Allah'ın ilminin maluma tabi olduğunu, kulun o bilgiden dolayı zorlanmadığını, öyle olunca yukarıdaki ayette geçen 'kitap' kelimesinin varlığın ve hayatın kanunu/sünnetullah olduğunu ifade eder. Bulaşıcı bir virüse maruz kalan bir insanın o virüsten etkilenmesi sünnetüllahın gereğidir. Virüse yakalanan birinin daha doğmadan böyle bir şeyle karşılaşacağı belirlenmiş değildir. Ayette geçen "önce" zarfı, insan doğmadan önce değil, olay meydana gelmeden önce, şeklinde anlaşılırsa, kader fikrine değil de insanın vücudu da dahil olmak üzere fizikî alemde işleyen yasa fikrine ulaşılır. ${ }^{77}$

Eş'arîyyenin bu uluhiyyet tasavvuru beraberinde cebriyeci bir kader anlayışı Eş’arîyye kelam sisteminden beslenen tasavvuf çevreleri ile halk arasında yaygınlık kazanmıştır. Bu düşüncenin bir sonucu olarak tevekkül inancı, tedbirleri gereksiz gören olup bitene seyirci kalan pasif bir teslimiyete dönüşmüştür. Nitekim Mehmed Akif, "Fatih Kürsüsünden",78 adlı manzum şiirinde Türk milletinin 'kader' anlayışını ‘cebriyeci’ bir hal aldığı gerekçesiyle şiddetle eleştirir.

2. Varlı̆̆a Bakış: Eş'arîyyenin ulûuhiyyet tasavvurunun en önemli yansıma alanlarından biri de varlık felsefesinde kendini göstermektedir. Bu düşüncenin genel olarak yapısı cevher/atom ve araz teorisine dayanmaktadır. Bu teori, ister cisim, ister fiil, isterse duyular olsun âlemdeki her şeyin yapısı salt bir komşuluk ve yakınlık esası üzerine kuruludur. Varlığı oluşturan atomlar arasında bir temas ve ilişki yoktur. Böyle bir sistemde nedensellik ve kanun düşüncesine yer yoktur. ${ }^{79}$ Böyle bir varlık felsefesine sahip olan Vesileci/okazyonalist düşünürlere göre tabiattaki varlıklar bir sonuç üretecek güç ve vasıfta değildirler. Âlemde görülen şeyler her an yaratılan ve yok edilen cevher ve arazlardan meydana gelmektedir. Onları da sürekli yaratan ve yok eden, âlemdeki değişimi ve dönüşümü gerçekleştiren sadece Allah'tır. Öyle olunca 'tabiat kanunu' diye bir şey yoktur. Âlem, Allah'ın sürekli ve her an tekrarlanan faaliyetiyle varlığııı sürdürmektedir.

Pek çok klasik kelamcının savunduğu ancak Eş'arî kelamcıların Eş’arî-Sûfiyyenin iman derecesinde kabul ettiği böylesi bir yaklaşım, nedenselliğin mutlaklaştırılmasına karşı oluşturulmuş bir düşüncedir. Elbette materyalistlerin/natüralistlerin nedenselliği mutlaklaştırmaları ateizme ya da deizme götürür. Fakat nedensellik, zaman bakımından birbirlerini takip eden ve böylece meydana gelen olayların sıradüzeni olarak da yorumlanabilir. Yani bir olay veya sonuç kendinden önceki bir başka olayın sonucu olmaktadır. Nitekim bir nesne veya değişmenin nasıl meydana geldiğini açıklarken meydana gelen sonuçtan hareketle sebebi araştırmak, insan zihninin bir işleyiş biçimidir. Tabiatçı filozofların, maddi bir varlığın, kendi tabiatı gereği veya başka bir maddi varlığın tabiatından kaynaklandığına dair iddiaları bunun ötesinde tabiatüstü herhangi bir illet veya failin olamayacağını iddia etmeleri, özellikle Eş'arî kelamcılarda tabiat fikrinden tamamen soyutlanmış bir teori geliştirmeye sevk etmiştir. ${ }^{80} \mathrm{Bu}$ bir yanlıştan uzaklaşırken başka bir yanlışa yönelmeye yol açmıştır. Çünkü bizler, ancak nedenselliğin varlığı sayesinde tabiat ilimlerine ulaşabilmekteyiz. Ayrıca tabiat kanunlarını keşfettiğimiz oranda ondan istifade ettiğimiz ve onların üzerine tekniği tesis ettiğimiz de

\footnotetext{
${ }^{76}$ Ebu Mansur Muhammed b. Muhammed el-Mâtüridî, Te'vilatu Ehli's-Sünne, thk. Fatıma Yusuf el-Hıyamî (Beyrut: Müessesetu'r-Rislale, 2004/1425), 5/50.

77 Şaban Ali Düzgün, “Kader'i Farklı Kategoriler İçinde Okumanın İmkânı”, Kelam Araştırmaları Derisi 11/2 (2013), 7.

${ }^{78}$ Mehmet Âkif Ersoy, Safahat, haz. A. Vahap Akbaş (İstanbul: Beyan Yayınları, 2009), 496-514.

${ }^{79}$ Eş’arî Düşüncesindeki atom nazariyesinin kökeni ve zamanla ulaştığı merhaleler konusunda bk. Richard M. Frank, Bodies and Atoms: The Ash'arite Analysis, çev. Hüseyin Aydın, D. ̈̈. İlahhiyat Fakültesi Dergisi 3/1 (2001), $95 \mathrm{vd}$.

80 Bk. İlhan Kutluer, "İlliyet”, Türkiye Diyanet Vakfi İslâm Ansiklopedisi (İstanbul: TDV Yayınları, 2000), 22/120-121.
} 
bir vakıadır. Öyle olunca insanın dünya hayatını sürdürebilmesi için, katı determinizme varmayan (soft determinism) bir nedenselliğe ihtiyacı vardır. Öyle ki Kur'an, Allah'ın kudretini farklı varlıklara paylaştıran müşriklere karşı sıkça Allah'ın kudretine dikkat çekse de âlemde bir nizamın varlığından söz etmektedir. Elbette kâinat muayyen kanunlara göre işlemektedir, ancak işleyiş asla Allah'tan bağımsız değildir. Her şey Allah'ın izni doğrultusunda gerçekleşir, denildiğinde bundan; her şeyin, Allah'ın o şeyin özüne yerleştirdiği ve o şeyi kendisi yapan yasaları doğrultusunda gerçekleştiği anlaşılmalıdır. Kur'an'daki ifadesiyle "sünnetullah" önce sebebi, sonra da neticeyi yaratma tarzında gerçekleşmektedir. ${ }^{81}$ Ancak Allah dilerse, herhangi bir sebebe bağlı kalmadan da neticeyi yaratabilir. Bunun gibi sebebi yarattığı halde bazen neticeyi yaratmayabilir. Peygamberlerin şahsında gerçekleşen ve mu'cize olarak ifade edilen Allah'ın yarattığı fiiller böyledir. Bu durumda Allah'ın fiillerini tabiat kanunları dahilinde olanlar ve tabiat kanunları dahilinde olmayanlar şeklinde ikiye ayırmamız mümkündür. Birinci kısımdakiler, sebep-netice zincirini bozmayan ve tabiat kanunlarıla izah edilebilen, sünnetullaha uygun olarak meydana gelmektedir. İkinciler ise nadiren vukua gelse de sebep-netice zincirini bozan, tabiat kanunlarıla açıklanamayan ve Sunnetullaha (sunnet-i amme) aykırı olarak yine Allah'ın diğer bir sunneti ile (sunnet-i hassa) ortaya çıkmaktadır.

Muhammed Abid el-Cabirî’ye göre sebep-sonuç ilişkisini kabul etmeyenlerin düşünce yapılarının arka planında Arapların İslam öncesi cağlarda süreklilik-bitişiklik(ittisal)esasına değil de süreksizlik-ayrışım (infisal) esası üzerine kurulu dünya görüşleri vardır. Bu bakış tarzına göre cahiliye dönemi Arap ilimlerinde olaylar arasında zorunlu sebep-sonuç ilişkisi anlamında bir sebeplilik düşüncesi yoktur. Bütün bu ilimler deliller üzerine değil, sırf emare ve ipuçlarına dayalı bir akıl yürütme üzerine kuruludur. Emare ise bir şeyin alameti olup onun illeti veya illete bağlı sonuç değildir. Hâlbuki sebeplilik ilkesi, Allah'ın belirlediği ve değiştirmeyeceğini beyan ettiği sebepler vasitasıyla meydana gelebilmektedir. ${ }^{82}$

İbn Rüşt'e göre Eş’arî kelamcıların nedenselliği kabul etmeme düşüncesinin kökleri cahiliyye dönemine uzanmaktadır. O bu konuda Eş'arîleri şöyle eleştirir:

"Bize göre etkin sebepler konusunda kafası karışık olup da işi karıştıranların ve illetin ma'lul ile alakasını idrak edemeyenlerin bu konuda bilmediklerini araştırmaları veya fen ilimleri öğrenmeleri gerekir. Çünkü bu, doğru olan bilimsel metodu belirleyen izah tarzıdır. Varlıklardaki olguları yalnızca adet olarak değerlendirmek ve bununla yetindirmek, dolayısıyla aklı araştırmaktan ve düşünmekten alıkoymaya çalışmak, kabul edilir bir durum değildir. Akı1 illetleri araştırma tabiatıyla donatılmıştır, varlıklar arasında ilişkileri ve bağları açıklama amacıyla sebebliliği yok saydığımızda, aklın görevi ne olacaktır? Akıl, bizatihi varlıkları nedenleriyle kavramasından başka bir şey değildir. İşte bununla o öteki kavrama yetilerinden ayrılır. O halde nedenleri reddeden kimse, aslında aklı da reddetmiş olmaktadır... Kaldı ki, Eş’arîlerin tutumlarında olduğu gibi, zorunlu hiçbir bilginin bulunmadığını kabul eden kimse, kendi sözünün de zorunlu olmadığını kabul etmek zorundadır. $\mathrm{Bu}$ durum, akıl, onun tabiatı ve etkinlik sahası açısındandır. Fakat eşya cihetinden olaya bakınca, kim algılanan varlıklardaki nedenselliği inkâr ederse o tabii sebepleri yok sayar, eşyanın sıfatlarını ve özünü kabul etmemiş olur." ${ }^{83}$

Fazlur Rahman ise bu konuda şunları söylemektedir:

“Tabiat, Allah’ın köklü bir şekilde yerleştirdiği kendi kanunları sayesinde işler. Yani tabiatta

\footnotetext{
${ }^{81}$ Abdülkerim Zeydan, es-Sünenü'l-İlahiyye fi'l-Ümemi ve'l-Cemaat ve'l-Ferd (Beyrut: Müessesetü’r-Risale, 1993), 60.

${ }^{82}$ Muhammed Abid el-Cabiri, Arap-İslam Kültürünün Akıl Yapısı (İstanbul: Kitabevi Yayınları, 2000), 50.

${ }^{83}$ İbn Rüşd, Tehafütü tehafüt, thk. Süleyman Dünya (Kahire: Daru'l-Mearif, 1963), 777-778.
} 
tabii nedensellik söz konusudur. Bu yüzden ona göreceli olarak bağımsız diyebiliriz. Fakat bu mutlak bir bağımsızlık değildir. Çünkü varlığı için tabiatın hiçbir garantisi yoktur ve kendi kendisinin nasıl işlediğini göstermekte yetersizdir. Kâinatta nedenselliğin olmadığını iddia etmek bir bakıma her an her şeyin değişebileceğini kabul etmek demektir. Bu ise Allah'ın evreni boş yere yaratması onu eğlence vasıtası kılması demektir. Hâlbuki Allah bundan münezzeh olduğunu bildirmektedir. Eş'arî düşüncesinde cevaz ilkesine ve atom nazariyesine bağlı olarak oluşturulan ontoloji anlayışı, Kur'an'a dayanan İslamî algılayıştaki düzen, insicam ve buna bağlı olarak Allah'ın yaratmasındaki süreklilik ve devamlılık ilkelerinin, en azından üstü örtülü bir şekilde feda edilmesine yol açmıştır. Eş'arîler bu yöntemi benimsemekle, Kur'an'ın defalarca vurguladığı, yerde ve göklerde uyumun ve düzenin hâkim olduğu ilkesini feda etmişlerdir. Bu şekilde bu düzenin sağlamlığı ve şaşmaz sürekliliği ile "Allah'ın öteden beri süregelen kanunu budur. Allah'ın kanununda asla bir değişiklik bulamazsın" ${ }^{84}$ ayetinin belirttiği hayatın daha başka pek çok yönündeki süreklilik ve düzeni hesaba katmamışlardır." 85

Yukarıda izah etmeye çalıştığımız varlığa bakış tarzı pek çok kimsede sebepler düzeyinde gerekli tedbirleri almadan ve kurallara uymadan doğrudan Allah'ın kendilerine yardım edeceği inancını doğurmuştur. $\mathrm{Bu}$ gün bu anlayışın trafikten sağlık kurallarına pek çok alanda alınması gereken önlemler ve uyulması gereken kuralların ihmal edilmesinde etkili olduğunu söyleyebiliriz. Çoğumuz pek çok kimsenin arabasının önüne veya arkasına büyük puntolarla "Allah Korusun” veya benzeri dualar yazdırdığını görmüşüzdür. Ama üzerinde bu duaların yazılı olduğu pek çok aracın kazaya karıştığını da şahit olmuşuzdur. Bu duanın kabul olması için öncelikle o aracı süren kimsenin yola çıkmadan önce ve sefer esnasında gerekli tüm tedbirleri almış olması gerekir. "Ey Rabbim! Yalnız sana ibadet eder yalnız senden yardım dileriz" diye namazın her rek'atında okuduğumuz Fatiha Suresi'nin 5. ayetindeki duamızın kabul olması için kulun Yüce Allah'ın tabiata yerleştirdiği ilahi yasaları ve eşyalar arasındaki sebep-sonuç ilişkisini bilip gereğince hareket etmesiyle mümkündür. Matlub olan yardım kulun, Yüce Allah'ın evrene yerleştirdiği İlahî yasaları bilip, İlahî emirleri uygulama safhasına intikal ettirirken, onlardan yardım dilemesidir. ${ }^{86}$

Cevaz ilkesi veya cevher ve araz nazariyesi kimi Mu'tezilî ve Mâtürîdî kelam âlimleri tarafından da savunulmuştur. Fakat Eş'arî kelamında bu nazariye alternatifsiz iman edilmesi gereken bir ilke gibi savunulmuştur. ${ }^{87} \mathrm{Bu}$ anlayışın bir sonucu olarak her hangi bir sebebin etkisini kabul etmek, tekfir edilme sebebi sayılmıştır. Öyle ki nedenselliği reddetmek, sıradan bir tartışma konu olmamış bu düşüncenin pratiğe yansıması, her şeyin doğrudan Allah'ın kudretine bağlanmasıyla tabiattan ve tabiatta işleyen Allah'ın kanunlarını araştırmaktan uzak kalmaya sebep olmuştur. Bu da din-dünya ilişkisindeki dengenin bozulmasında ve Müslümanların tabiata yönelmelerini engelleyen önemli bir etken olmuştur. Elbette tabiatta her şeyin sürekli değişiğine, sabit hiçbir şeyin bulunmadığına, sebeplerin sonuçlar üzerinde hiçbir şekilde etkili olmadığına inanan kimselerden ısrarla planlı programlı bir şekilde tabiata yönelip onun üzerinde tefekkür edip gözlem ve araştırma yapmaları beklenemez.

Yukarıda ifade ettiğimiz Eş'arî kelamcıların insan ve kâinata yönelik yorumları zamanla Müslüman toplumların kültürleriyle bütünleşince, kader ve tevekkül gibi bazı İslam inançları, tembelliğe adeta kılıf olmuş, vurdumduymazlık, hazırla yetinme, ortaya çıkan problemlere köklü

\footnotetext{
${ }^{84}$ Fetih 48/23.

${ }^{85}$ Fazlurrahman, Ana Konularıla Kur'an, çev. Alparslan Açıkgenç (Ankara: Ankara Okulu Yayınları, 1998), 118-119.

${ }^{86}$ Takiyyüddin Ebu'l-Abbas Ahmed b. Abdülhalim İbn-i Teymiyye, Mecmû'u Fetâvâ (Riyad: 1991), 8 / 76.

${ }^{87}$ Tevbe, Limaza Sagatat el-Hilafetü'l-Osmaniyye, $60 \mathrm{vd.}$
} 
çözümler getirme yerine kısa vadede günü kurtaracak uygulamalar bazı kesimlerin genel karakteristiği haline gelmiştir. ${ }^{88}$ Batı'da Rönesans ile birlikte hızlı bir şekilde hem sosyal hem de deneysel bilimlerde ciddi gelişmelerin yaşandığı, çok farklı teorilerin ortaya atılıp tartışıldığı bir dönemde, İslam kültür ve medeniyetini temsil eden Osmanlı medreselerinde felsefe ve fen bilimlerine gerekli ihtimamın gösterilmediği, gelişen şartlara göre yeni ilimlerin konmadığı bilinmektedir. ${ }^{89}$ Daha sonraki süreçlerde bilimden kültüre, ekonomiden savunmaya pek çok alanda Müslüman toplumların Batı'ya karşı üstünlüğünü kaybettiği hepimizin malumudur.

\section{SONUC}

Her din doğuşundan bir müddet sonra farklı yorumlara tabi tutulur. Aynı dine mensup olmakla birlikte farklı coğrafyalarda yaşayan, farklı kültürlere mensup insanlar bazı konularda farklı kanaate sahip olabilmektedirler. İslam dini için de bu durum aynı şekilde gerçekleşmiştir. Hz. Peygamberin vefatıyla birlikte teslimiyetçi dönem yavaş yavaş kaybolmuş, iç ve dış kaynaklı bazı olaylar itikadîsiyasi ve ameli mezheplerin doğmasına yol açmıştır. Ancak İslam dini açık ve anlaşılır bir inanç sistemine sahip olduğu için aşırı yorumcu(gulat) fırkaları hariç tuttuğumuzda, başta Ehl-i sünneti oluşturan Selefiyye, Eş'arîyye ve Mâtürîdiyye olmak üzere itikadî mezhepler arasında ciddi ihtilaflar yoktur. Fakat farklı kelam metotları çerçevesinde söz konusu akaid sisteminin yorumları beraberinde ihtilafları kaçınılmaz kılmaktadır.

Eş'arîyye ile Mâtürîdilik arasındaki ihtilaflar da kelâmî yorumlar olarak değerlendirildiğinde önemsiz sayılabilir; ancak bireysel ve sosyal hayattaki sonuçları dikkate alındığında ciddi ihtilaflar olduğunu söyleyebiliriz. Özellikle Eş'arîyyenin Allah tasavvuru ve bu tasavvurun bir sonucu olarak ortaya çıkan insan anlayışı pek çok tartışmanın kaynağı konumundadır. Modern çağ Batı düşüncesinde Allah-insan ilişkisi ile ilgili tartışmalar, yeni felsefi akımların doğmasına yol açmıştır. Aydınlanma felsefesini ve bunun içerisinde bir özne olarak insanı ön plana çıkarmak isteyen hümanizm ve egzistansiyalizm/varoluş̧̧uluk bunlardan bazılarıdır. Söz konusu felsefi akımlara mensup düşünürler, Hıristiyanlığın tanrı tasavvuru üzerinden tüm ilahi dinlerin Allah inancını şiddetle eleştirmişlerdir. Onlara göre teizmin Tanrı'sı insanın özgürlüğünü yok etmektedir. Aklını kullanmasına ve üretken bir kişilik sergilemesine engel olmaktadır. Bu düşünürler, insanın böyle bir konuma düşmesini kendine yabancılaşması olarak nitelemektedirler.

Modern çağda Batı düşüncesinde ortaya çıkan inkârcı düşünce akımları kısa bir süre sonra İslâm dünyasında da yankı bulmuştur. İslam toplumlarında Ateizme ya da deizme yönelen kişilerin dine yönelik pek çok itirazları olmakla birlikte söz konusu itirazların önemli bir kısmı Eş’arîyyenin Allah tasavvuru ve kader inancına yöneliktir. Bu bağlamda ateistlerin veya deistlerin, Eş'arîyye'nin Allah tasavvuru, kader inancı ve insana bakışlarına yönelik itirazları söz konusu olduğunda, Mâtürîdî kelamcıların bu konulardaki yorumlarının öne çıkarılmasının daha isabetli olacağı kanaatindeyim.

Kelamî yorumlar, inanç önermeleri olmadığına göre yukarıda ifade ettiğimiz gibi çağımızda Allah-insan ilişkisi konusunda Mâtürîdiyyenin görüşlerini öne çıkarmayı gerekli kılıyor ise de bir başka konuda Eş'arîyyenin bir görüşü öne çıkarılabilmelidir. Bu bakımdan İslâm coğrafyasında üretilmiş ve bu toprakların düşünme biçimini oluşturmuş olan iki büyük ekolü birbirine rakip olarak

\footnotetext{
${ }^{88}$ Eş’arîyye kelamında sebeplilik düşüncesin sonuçları ve yansımaları konusunda bk. Fethi Kerim Kazanç, Varlık, Bilgi ve Siyaset Üzerine Kelam Yazıları (Ankara: Araştırma Yayınları, 2014), 84-97.

${ }^{89} \mathrm{Bk}$. Mustafa b. Abdullah Katib Çelebi, Keşfu'z-zunun an-Esmai'l-Kütübi ve'l-Fünun (İstanbul: Matbaatu'lBehiyye, 1941), 1/680; Aykut Kazancıgıl, Osmanlılarda Bilim ve Teknoloji (İstanbul: Gazeteciler ve Yazarlar Vakfı Yayınları, 1999), 133-134; İlyas Çelebi, "Osmanlı Medreselerinin Kuruluşu, Yükselişi ve Çöküş Nedenleri”, Osmanlı Ansiklopedisi (İstanbul: 1998), 5/173-174.
} 
görmemek gerekir. Her iki ekolü kendi sınırları ve şartları içerisinde anlamaya çalışmak ve buradan yeni değerlendirme imkânı elde etmek gerekir. Eş'arî-Mâtürîdî ihtilafı haddizatında Ehl-i sünnet düşüncesi içerisinde dinamizm imkânı tanımaktadır. Böylece hem tek tipleşme tehlikesinden korunma imkânı ede edilmiş olur. Bu bakımdan Eş'arîlik ve Mâtürîdîliğin tek başlarına taşıdıkları değerden çok daha önemlisi, bütün farklılıklarıyla birlikte oluşturdukları Ehl-i sünnet çerçevesidir. Bu iki ekolün tarihsel ve sosyolojik bir gerçeklik olarak farklı kültür havzalarında ortaya çıktıkları ve varlıklarını buralarda devam ettirdikleri herkesin kabulüdür. Örneğin Mâtürîdîlik ile Türk kültür havzası arasında bu türden bir ilişki söz konusudur. Ancak bu ilişkinin, ideolojik milliyetçilik üzerinde okunması, kanaatimizce büyük hata olur. Hanefî-Mâtürîdî geleneğin büyük ölçüde Türk kültür havzasında üretilmiş olması, bu geleneğin günümüz ideolojik perspektifinden, milliyetçilik için üretilmiş olduğu sonucunu doğurmaz. Ayrıca bu zamana kadar ihmal edilmiş olan Mâtürîdî kelamını daha geniş çevrelere ulaştırmak yerine dar bir alana hapseder. Bu bakımdan çağımızda karşı karşıya kaldığımız pek çok inanç probleminin çözümünde önemli katkılar sağlayacağına inandığımız Mâtürîdî kelamına ilmi bir zihniyetle yaklaşılması büyük önem arz etmektedir.

\section{KAYNAKÇA}

Akman, Mustafa. "Eş’arîlerin Nedensellik Anlayışı Üzerinden Hadisçilerin Vardığı Sonuçlar”. Journal of Islamic Research 22/2 (2011), 71-88.

Akoğlu, Muharrem. "Büveyhîler'in Mezhebî Eğilimleri/Politikaları Üzerine". Bilimname 17/1 (2009), 123-138.

Akoğlu, Muharrem. Büveyhîler Döneminde Mu’tezile. Ankara: İlahiyat Yayınları, 2008.

Aynî, Mehmet Ali. “Türk Mantıkçıları”. Daru'l-Fünûn İlahiyat Fakültesi Mecmuası 10/3(1928), 52-53.

Bağdadî, Abdulkahir. el-Fark Beyne'l-Fırak. Beyrut: Daru'l-Marife, 2.Bask1, 1997.

Bakıllanî, Kadı Ebu Bekr Muhammed. Kitabu't-Temhid. nşr. R. MC. Carthy, Beyrut:1957.

Cabiri, Muhammed Abid. Arap-İslam Kültürünün Akıl yapısı. çev. Burhan Köroğlu - Hasan Hacak. İstanbul: Kitabevi Yayınları, 2000.

Coşkun, İbrahim. “Teşbih ile Tenzih Arasında S. Âmidî’nin Allah'ın Sıfatlarını Yorumlamadaki Metodu”. Dicle Üniversitesi Illahiyat Fakültesi Dergisi 3/2 (2002), 23-59.

Çelebi, İlyas. “Osmanlı Medreselerinin Kuruluşu, Yükselişi ve Çöküş Nedenleri”, Osmanlı Ansiklopedisi. ed. Güler Eren. 5/168-174. Ankara: Yeni Türkiye Yayınları, 1999.

Çelebi, Mustafa b. Abdullah Katip. Keşfu'z-zunun an-Esmai 'l-Kütübi ve'l-Fünun. İstanbul: Matbaatu'l-Behiyye, 1941.

Dalkılıç, Mehmet. “Buhara'nın İslamlaşmasında Kuteybe b. Müslim'in Rolü”, Uluslararası Sosyal Araştırmalar Dergisi 5/23 (Güz 2012), 149-156.

Devvânî, Celaleddin. Celâl Şerhu’l-Akâidi'l-Adudîyye. İstanbul: Matbaa-1 el-Hac Muharrem Efendi el-Bosnevî, 1290.

Düzgün, Şaban Ali. “Kader'i Farklı Kategoriler İçinde Okumanın İmkânı”, Kelam Araştırmaları Dergisi 11/2 (2013), 1-10.

Ebu'l-Fidâ, Imadüddîn İsmail b. Ali b. Mahmud. Tarihû Ebi'l-Fidâ. thk. Mahmud Deyyûb. Beyrut: 1997.

Ersoy, Mehmet Akif. Safahat. haz. A. Vahap Akbaş. İstanbul: Beyan Yayınları, 2009.

Eş'arî, Ebu'l-Hasen. el-Luma. nşr. Richard Mc. Carthy. Beyrut: 1952.

Fazlur Rahman. Ana Konularıyla Kur'an. çev. Alparslan Açıkgenç. Ankara: Ankara Okulu Yayınları, 1998.

Fazlur Rahman. İslam ve Çağdaşlık. çev. Alparslan Açıkgenç. Ankara: Ankara Okulu Yayınları, 1996.

Frank, Richard M. Bodies and Atoms: The Ash'arite Analysis. çev. Hüseyin Aydın. D.Ü. İlâhiyat Fakültesi Dergisi 3/1 (2001), 95-109.

Gazzalî, Ebu Muhammed b. Muhammed. Faysalu't-Tefrika Beyne'l-İslam ve'z-Zenadika. nşr. Süleyman Dünyan. Kahire: 1961.

Gazzalî, Ebu Muhammed b. Muhammed. thk. Abdurrahman Bedevî. Kahire: el-Mektebeu'l-Arabiyye,1963.

Gölcük, Şerafettin. Kelam Tarihi. İstanbul: Kitap Dünyası Yayınları, 5. Baskı, 2009.

Halil, İmaduddin. Melamihu 'l-İnkilabi'l-İslami fi Hilafeti Ömer b. Abdülaziz. Beyrut: er-Risale, 7. Bask1, 1985.

Hamevî, Ebu Abdillah Şihâbuddin Yakut. Mu'cemu'l-Buldan. Beyrut: Daru sadr, 1907.

İbn Hallikan, Ebu'-1 Abbas Şemsüddin Ahmed b. Muhammed. Vefeyâtu'l-Ayân ve Enbai'z-Zaman. thk. İhsan Abbas, Beyrut: Daru sadr, 1977.

İbn Hümam, Kemaleddin. el-Müsayere. İstanbul: 1979.

İbn Kesîr, Ebu'l-Fidâ. el-Bidâye ve'n-Nihâye. nşr. Hasan Abdülmennan. Beyrut: Beytü'l-Efkari'd-Devliyye, 2004.

İbn Rüşd. Tehafütü tehafüt. thk. Süleyman Dünya. Kahire: Daru'l-Mearif, 1963.

İbn Teymiyye, Takiyyüddin Ebu'l-Abbas Ahmed b. Abdülhalim. Mecmû'u Fetâvâ. Riyad: 1991.

İbnü'l-Cevzî, Ebu'l-Ferec Abdurrahman b. Ali. el-Muntazam fi Tarihi'l-Mülük ve'l-Ümem. thk. Muhammed Abdülkadir Ata - Mustafa Abdülkadir Ata. Beyrut: Daru'l-Kütübi'l-ilmiyye, 1995.

İbnü'l-Esîr, Ebu'l-Hasen İzzüddîn Ali b. Muhammed. el-Kâmil fi 't-Târih. Beyrut: Daru'l-kütübi'i-ilmiyye,1979.

İbnü'l-Esîr, Ebu'l-Kasım Ali b. Hasan b. Hibetullah. Tebyînu Kezibi'l-Müfteri. nşr. M. Zahid el-Kevserî. Beyrut: Daru'lkütüb'l-Arabî, 1979.

Kazancıgil, Aykut. Osmanlılarda Bilim ve Teknoloji. İstanbul: Gazeteciler ve Yazarlar Vakfı Yayınları, 1999. 
Kazanç, Fethi Kerim. "Bilge Vezir Nizamülmülk”. Gazzâlı̂’nin Feâhihu'l-batiniyye Adlı Eseri Muvacehesinde Batin̂̂ Akımlarla Mücadele. ed. Musa Kazım Arıcan - Muhammed Enes Kala - Mehmet Tuğrul, Konya: Konya Büyükşsehir Belediyesi Kültür Yayınları, 2019.

Kazanç, Fethi Kerim. Varlık, Bilgi ve Siyaset Üzerine Kelam Yazıları. Ankara: Araştırma Yayınları, 2014.

Kazanç, Fethi Kerim. "Eş'arî Kelam Sisteminde Allah Anlayışı ve Doğurduğu Sorunlar", Tanrı Tasavvurları ve Sosyal Hayata Yansımaları Sempozyumu. ed. Ramazan Biçer - Süleyman Akkuş. Sakarya: SÜ İlahiyat Fakültesi Yayınları, 2005.

Kitapçı, Zekeriya. Orta Asya'da İslamiyet'in Yayılışı ve Türkler. Konya: Damla Ofset, 1994.

Korkmaz, Sıddık. İmâm Mâtürîdî ve Mezhep Eleştirileri. İstanbul: İz Yayıncılık, 2017.

Kureşî, Muyhiddin Ebu Muhammed Abdülkadir b. Muhammed. el-Cevâhiru'l-Mudiyye fi Tabakâti'l-Hanefiyye. thk. Abdülfettah Muhammed el-Hulv. Beyrut: Daru hicr,1993.

Kuşeyrî, Abdülkerim. Kuşeyrî Risalesi. haz. Süleyman Uludağ, İstanbul 1978.

Kutluer, İlhan. "İlliyet”, Türkiye Diyanet Vakfi İslâm Ansiklopedisi. 22/120-121. İstanbul: TDV Yayınları, 2000.

Madelung, Wilferd. "Mâtürîdiliğin Yayılışı ve Türkler". çev. Muzaffer Tan. İmam Maturîdî ve Mâtürîdilik. haz. Sönmez Kutlu. 305-368. Ankara: 3. Bask1, 2011.

Mâtürîdî, Ebu Mansur Muhammed b. Muhammed. Te'vilatu Ehli's-Sünne. thk. Fatıma Yusuf el-Hiyamî. Beyrut: Müessesetu'r-Rislale, 2004/1425.

Mâtürîdî, Ebu Muhammed b. Muhammed. Kitabu't-Tevhîd. Ankara: İsam Yayınları, 2003.

Muheymid, Ali b. Salih. "Karahanlılar ve İslam'ın Yayılmasına Katkıları”. çev. Ali Aksu. Cumhuriyet Üniversitesi İlahiyat Fakültesi Dergisi 5/1 (2001), 281-310.

Numan b. Sabit, Ebu Hanife. "el-Fıkhu'l-Ebsad”. haz. Mustafa Öz. İmam-ı Azamın Beş Eseri. İstanbul: İFAV Yayınlar,1992.

Ocak, Ahmet. "Medrese Geleneği İçinde Nizamiye Medreselerinin Önemi ve İlim Dünyasına Kazandırdığı Yenilikler". Selçuklular'da Bilim ve Düsünce. Konya: Türk Tarih Kurumu, 2013. 441-462.

Ocak, Ahmet. Selçuklular'ın Dini Siyaseti. İstanbul: Tatav Yayınları, 2002.

Oğuz, Muhammed İhsan. İslam'da Kaza ve Kader. İstanbul: Oğuz Yayınları, 2. Baskı, 1993.

Özaydın, Adülkerim. "Nizâmiye Medresesi". Türkiye Diyanet Vakfi İslâm Ansiklopedisi. 33/188-191. İstanbul: TDV Yayınları, 2007.

Özbek, Durmuş. Saduddin Teftazani ve Nüvvet Görüşü. Konya: 2002.

Özcan, Hanefi. Maturîdî'de Dini Çoğulculuk. İstanbul: İFAV Yayınları, 1999.

Özervarlı, Said. Kelamda Yenilik Arayışları. İstanbul: İsam Yayınları, 2008.

Özler, Mevlüt. İslâm Düşüncesinde Tevhid. İstanbul: Nun Yayıncılık, 1995.

Râvendî, Muhammed b. Ali b. Süleyman. Râhatü's-Südûr. çev. Ahmet Ateş, Ankara 1957.

Razi, Fahreddin. Allah'ın Aşkınlığ 2018.

Subkî, Tacuddin Ebu Nasır Abdulvehhab b. Ali. et-Tabakâtu'ş-Şafî̀yyetu'l-Kübra. nşr. Abdulfettah Muhammed el-HulvMahmut Muhammed et-Tenâhî. Haleb: Daru hicr, 1964.

Şehristanî, Ebu'l-Feth Muhammed b. Abdülkerim. Kitabu'l-milel ve'n-nihal. thk. Muhammed Fehmi Muhammed. Beyrut: Daru'l-kütüib'l-ilmiyye, t.y.

Şehristanî, Muhammed Abdulkerim. Nihayetu'l-Ikdam fi-İlmi'l-Kelam. thk.-nşr. A. Guillauuame. Londra:1934.

Taberî, Ebu Cafer Muhammed b. Cerir. Tarihu'l-Ümem ve'l-Mülük. nşr. Ebu Suayb el-Keremî. Ürdün: t.y.

Taneri, Aydın. "Büyük Selçuklu İmparatorluğunda Vezîrlik". Tarih Araştırmaları Dergisi 5/8 (1967), 75-186. https://doi.org/10.1501/Tarar_0000000299

Teftazanî, Saduddin. Haşiyetü Kestelli ala Şerhu'l-Akaid. İstanbul: Salah Bilici Kitabevi,1966.

Teftazanî, Saduddin. Şerhu'l-Makasıd. Beyrut: 1989.

Tevbe, Gazî. Limaza Sagatat el-Hilafetü'l-Osmaniyye. Beyrut: Mektebetu'l-İslamî, 2008.

Topaloğlu, Bekir. Mâtürîdîyye Akaidi. Ankara: Diyanet İșleri Başkanlığı Yayınları, 1979.

Turan, Osman. Selçuklular Tarihi ve Türk İslam Medeniyeti. İstanbul: Boğaziçi Yayınları, 5. Baskı, 1996.

Uludağ, Süleyman. Kelam İlmi ve İslam Akaidi. İstanbul: Dergah Yayınları, 1980.

Ünal, İsmail Hakkı. İmam Ebu Hanife'nin Hadis Anlayışı ve Hanefi Mezhebinin Hadis Metodu. Ankara: Diyanet İşleri Başkanlığı Yayınları,1994.

Watt, William Montgomery. İslam Düşüncesinin Teşekkül Devri. çev. Ethem Ruhi Fı̆̆lalı, Ankara: Umran Yayınları,1981.

Watt, William Montgomery. Íslam Felsefesi ve Kelam. çev. Süleyman Ateş. İstanbul: Pınar Yayınları, 2004.

Yaltkaya, Mehmed Șerefeddin. "Selçûkîler Devrinde Mezâhîb". haz. Seyit Bahçıvan. Marife 2/2 (Güz 2002), 265-276.

Yavuz, Abdullah Ömer. Büyük Selçuklu Sultanı Tuğrul Bey Döneminde Mu’tezile. Kayseri: Erciyes Üniversitesi, Sosyal Bilimler Enstitüsü, Yüksek Lisans Tezi, 2015.

Yavuz, Abdullah Ömer. "Büyük Selçuklu Devleti'nin Kuruluş Devrinde Mezhep Politikaları”. Bilimname 34 (Ekim 2017), 511-532. https://doi.org/10.28949/bilimname.348096

Yavuz, Yusuf Şevki. "Kader”. Türkiye Diyanet Vakfi İslâm Ansiklopedisi. 24/ 58-63. İstanbul: TDV Yayınları, 2001.

Yazır, Muhammed Hamdi. Hak Dini Kur'an Dili. İstanbul: Eser Kitabevi, 1971.

Zeydan, Abdülkerim. es-Sünenü'l-İlahiyye fi'l-Ümemi ve'l-Cemaat ve'l-Ferd. Beyrut: Müessesetü'r-Risale, 1993. 